\title{
Política e economia na Terceira República francesa: Emile Moreau e a batalha do franco
}

\author{
Rogério Arthmar
}

\section{Introdução}

Numa quinta-feira, 16 de julho de 1926, o ministro das finanças do décimo gabinete de Aristide Briand (sexto do Cartel des Gauches), ${ }^{1}$ Joseph Caillaux, encaminha à Câmara dos Deputados projeto de ajustamento financeiro do país no qual se inscrevia cláusula mediante a qual o Parlamento delegava-lhe amplos poderes a fim de reverter a derrocada da moeda nacional. A situação não poderia ser mais crítica. A libra esterlina, cotada em 173 francos no dia 30 de junho, atingia a marca de 202 francos em 16 de julho, acelerando a depreciação iniciada no ano anterior. No dia seguinte, quando a proposta chega ao plenário legislativo, a oposição é ferrenha. Edouard Herriot, presidente da Câmara, do Partido Radical e ex-primeiro ministro do Cartel, surpreende a todos ao exigir a retirada imediata do projeto por atentar, em suas palavras, contra as prerrogativas da instituição parlamentar e as consciências republicanas. Em meio aos inúmeros pronunciamentos contrários à proposta, o deputado André Tardieu lê trecho de um antigo plano secreto, intitulado Rubicon, no qual Caillaux arquitetara empalmar a Presidência da República e comandar o país por decretos, acusando o ministro das finanças de, mais uma vez, pretender implantar um governo ditatorial. Em que pesem as explicações de Caillaux em favor da urgência de certas medidas tributárias, o ministério Briand termina derrubado por 288 a 243 votos. Herriot é convocado pelo Presidente Gaston Doumergue, na noite de domingo, a constituir novo conselho. Na segunda-feira, a libra alcança alucinantes 235 francos (Figura 1). Quando alvorece a terça-feira, o público se desespera e toma os corredores e as escadarias do Palácio Bourbon. O novo gabinete Herriot não sobrevive ao pânico financeiro, sendo derrotado já em sua primeira votação, para aplausos da multidão que assediava o Parlamento. Findava ali a turbulenta história do Cartel des Gauches. O caminho estava aberto para o retorno triunfal de Raymond Poincaré, a quem logo a seguir seriam concedidos os poderes negados ao seu antecessor na condução da gigantesca tarefa de salvamento da moeda nacional. ${ }^{2}$

O desfecho desse célebre episódio da história política da Terceira República era de se antever. Figura controversa, Caillaux alcançara o apogeu no pré-guerra quando, ainda jovem, projetara-se como ministro das finanças dos gabinetes Waldeck-Rousseau (1899-1902) e Clemenceau (1906-1909). Em maio de 1911, Caillaux assume a presidência do conselho e, em 1o de julho, a Alemanha envia o canhoneiro Panther ao porto marroquino de Agadir visando intimidar as açôes francesas na região. Diante da ameaça de enfrentamento, o financista premier negocia um acordo cedendo parte considerável do Congo aos alemães. Acusado de fraqueza por capitular à chantagem germânica, Caillaux não resiste à pressão e é sucedido por Poincaré em janeiro de $1912 .{ }^{3}$ Quando o "linha dura" Clemenceau retoma o governo, em novembro de 1917, solicita ao Parlamento a imediata retirada da imunidade parlamentar de Caillaux, suspeito de conspirar com agentes a soldo alemão. Sob vigilância, o ex-ministro instrui a esposa Henriette, então em Roma, a recolher documentos confidenciais depositados no cofre de um banco em Florença. O embaixador francês na Itália toma conhecimento do pedido, aciona a polícia local e consegue lançar mão do material, contendo o projeto Rubicon, no qual Caillaux planejava tomar o poder como Presidente, governar por decretos e promover uma paz negociada com a Alemanha. Emerge, em seguida, toda uma rede de contatos supostamente incriminadores de Caillaux com o financista Bolo Pasha, executado por traição ao final da guerra, e com o jornal pacifista Bonnet Rouge. Preso em janeiro de 1918, Caillaux será julgado em 1919 pelos senadores e condenado a três anos de detenção, com privação dos direitos políticos por dez anos. ${ }^{4}$ Anistiado pelo Cartel em novembro de 
1924, elege-se pelo departamento da Sarthe, no ano seguinte, ao Senado, onde permaneceria por mais duas décadas como presidente da Comissão de Finanças. ${ }^{5}$

Figura 1. Cotações da libra em francos, 1919-1927 (médias mensais)

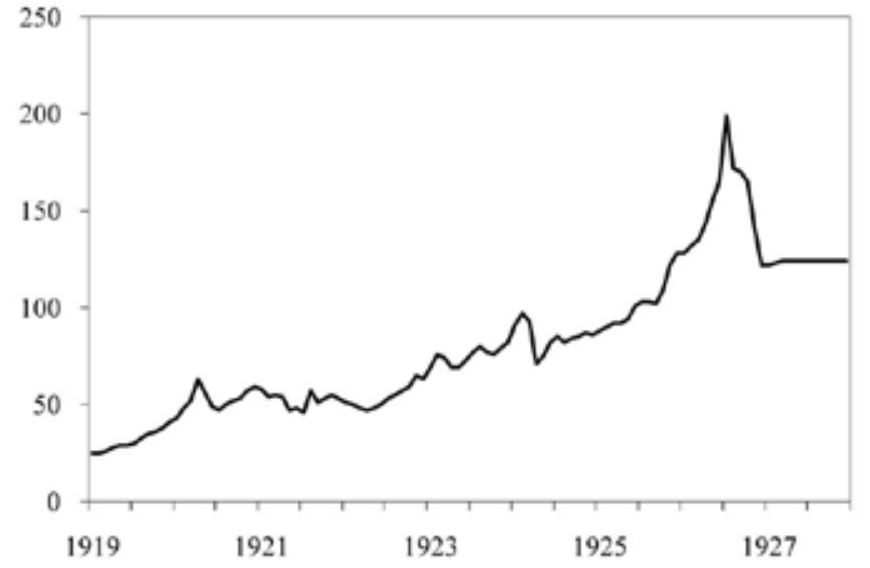

Fontes: La restauration financière de la France, de Raymond Poincaré (Annexe VIII) e Le credit public, de George Lachapelle (p. 439-441)

Se a queda de Briand, ocasionada pelo repúdio a Caillaux, permite divisar no horizonte a ascensão de Poincaré, ela, não obstante, reveste-se de amplo significado em termos da política de estabilização a ser adotada a seguir pela França. Em primeiro lugar, porque Caillaux, no ano anterior, já ocupara a pasta das finanças do gabinete Painlevé durante pouco mais de seis meses, quando a sua posição contrária ao imposto sobre o capital alienara as bases de apoio do ministério junto ao Cartel. Briand, político de larga experiência, sondara Poincaré e o senador Paul Doumer para as finanças, mas sem sucesso. A escolha final por Caillaux, embora de alto potencial explosivo, não se tratou, como será visto, de mera afinidade pessoal. O próprio Briand, no ano anterior, repreendera severamente Caillaux por ingressar na composição de Painlevé, antecipando os problemas que daí adviriam ao governo. Se, em junho de 1926, ele parece rever completamente a sua posição, o fato decorre de sua escolha envolver uma nova estratégia econômica a ser adotada na estabilização do franco. ${ }^{6} \mathrm{E}$, nesse sentido, uma atitude fundamental que somente esse personagem controverso da cena política da época poderia ter tomado, mas não Poincaré ou Doumer, homens conservadores, consistiria na troca irrevogável do escalão superior do Banco da França. Caillaux, num de seus primeiros atos oficiais, demite o diretor geral ${ }^{7}$ Georges Robineau $^{8}$ e o substitui por Emile Moreau, a quem o destino reservaria papel central na condução da política monetária do país durante a fase crítica de retorno ao padrão-ouro.

A literatura especializada, notadamente a partir de 1970, assistiu a um ressurgimento do interesse na estabilização do franco na década de 1920, especialmente nos trabalhos de Gregory C. Schmid, Stephen Schucker, Thomas Sargent, Pierre Sicsic, Fábio Giambiagi e, mais recentemente, Bertrand Blancheton (2001). ${ }^{9}$ Embora, com justiça, Poincaré ocupe papel de destaque nesses estudos, o presente artigo, ao privilegiar a obra de Emile Moreau, pretende apresentar uma visão alternativa do processo de estabilização do franco, momento crítico no qual se conclui a tarefa de reconstrução financeira internacional do padrão-ouro no período do entreguerras. ${ }^{10}$ Assim, no que segue, o presente artigo busca, em primeiro lugar, resgatar os fatores determinantes de remoção da alta cúpula do Banco da França por Caillaux, evento preparatório fundamental na subsequente restauração monetária do país. Em segundo lugar, apresentam-se as ações mais relevantes do novo diretor geral em seu embate com Poincaré nos meses decisivos da segunda metade de 1926, quando se prepara a estabilização de facto do franco. Para tanto, recorrer-se-á largamente aos registros diários de Moreau à época, publicados postumamente, em 1954, sob o título Souvenirs d'un gouverneur de la Banque de France. ${ }^{11}$ Trata-se de registro raro e deta- 
lhado dos bastidores das operaçōes do Banco da França durante a grande batalha pelo resgate da moeda nacional, a ser interpretado no contexto maior dos desafios econômicos do período. Por fim, em terceiro lugar, avalia-se a medida efetiva do distanciamento entre as visões de Poincaré e Moreau, no tocante ao reerguimento do franco.

\section{O legado de guerra e o dilema de Briand}

Após a demissão coletiva de seu nono gabinete, em 15 de junho de 1926, Briand tentara alinhavar uma ampla composição de união nacional que, contudo, terminara rechaçada pelos socialistas em vista de eventual conjunção com a direita eliminar as perspectivas de um imposto sobre o capital. Herriot, no dia 19, fora designado a constituir novo conselho, mas os seus esforços durante a madrugada (la folle nuit) resultaram infrutíferos devido à recusa dos conservadores em colaborar com o radical por considerá-lo incapaz de restabelecer a confiança junto à opinião pública. ${ }^{12}$ Briand, portanto, no momento em que retoma as negociações para formar um novo governo, o faz com relutância, esgotado pela debilidade do apoio parlamentar oferecido pelo Cartel. Poincaré é o primeiro a quem convida a assumir a pasta das finanças, mas o ex-presidente condiciona o ingresso no ministério a uma majoração imediata de oito bilhōes de francos nos impostos. Isso significava, para Briand, que o preço da adesão dos conservadores se elevara consideravelmente, trazendo consigo a perspectiva de intermináveis polêmicas na Câmara e no Senado, como a experiência legislativa do pós-guerra demonstrara à exaustão em matérias tributárias. ${ }^{13}$ Briand consulta então o moderado Doumer para ocupar o cargo, mas o senador reproduz as condições de Poincaré. O dilema, por conseguinte, estava posto. A quem apelar?

A causa mais profunda da encruzilhada diante de Briand radicava-se na situação econômica do país herdada do conflito. Durante a guerra, não mais do que uma fração aproximada de $15 \%$ das maciças despesas públicas havia sido coberta por expansão dos impostos. Os gastos restantes foram financiados numa proporção de $11 \%$ pelos adiantamentos do Banco da França e os demais três quartos por endividamento, dos quais praticamente a metade por títulos de curto prazo. ${ }^{14} \mathrm{~A}$ vitória aliada e a Conferência de Versalhes somente agravariam os problemas financeiros do país. De uma parte, as perdas humanas, os milhares de mutilados e a devastação dos territórios ocupados pelos alemães viriam a expandir vigorosamente os desembolsos orçamentários nas rubricas de pensões, indenizaçōes e reconstrução ${ }^{15}$ (Tabela 1). De outra, a estipulação de vultosas reparaçoos pela Alemanha bloqueava qualquer iniciativa doméstica de avanço significativo dos impostos porquanto insinuaçôes do gênero eram logo traduzidas como tentativas de se penalizar o contribuinte francês em favor do inimigo, o grande devedor da pátria. ${ }^{16}$ Restava ao governo buscar na expansão do endividamento interno a cobertura dos déficits recorrentes em suas contas.

A despeito das reformas tributárias parciais aprovadas no período, como a instituição do imposto sobre as vendas (taxe sur le chiffre d'affaires) no valor de 1\%, em 1920, ou o aumento geral de $20 \%$ nos impostos (double décime), aprovado em 1924, a dívida acumulada do governo central, especialmente em títulos de curto prazo, alcançava patamar demasiadamente perigoso. Em julho de 1926, os sucessivos empréstimos promovidos pelo Tesouro perfaziam um endividamento doméstico total de 281,7 bilhões de francos, valor já superior à renda nacional daquele ano (278 bilhōes), dos quais 42,2 bilhões em dívida de curto prazo (3 a 10 anos) e 94,2 bilhões em dívida flutuante, sendo 44,2 bilhões em Bons de la Défense Nationale e 37,4 bilhōes em adiantamentos do Banco da França. ${ }^{17}$

Até ali, portanto, a única doutrina econômica referida nos debates legislativos e nos meios financeiros consistia na obtenção dos pagamentos de reparação da Alemanha a fim de equilibrar o orçamento fiscal e amortizar a dívida pública, permitindo assim o restabelecimento do franco do pré-guerra apoiado num robusto lastro em ouro no Banco da França. ${ }^{18}$ Mas sem o apoio de seus aliados, especialmente dos Estados Unidos e da Inglaterra, a França, a rigor, não detinha pujança material e militar suficiente para impor a sua vontade à Alemanha, o que se revelaria por completo ao final da ocupação do Ruhr em 1925. ${ }^{19}$ Diante desse cenário, ou seja, da impossibilidade de contar com o aporte de largos 
recursos alemães, o austero orçamento de 1925 elaborado por Étienne Clémentel, ministro das finanças de Herriot, foi o primeiro a apresentar as contas públicas de forma consolidada e sem déficit. Tal vitória, todavia, jamais viria a ser capitalizada, pois, nesse ponto, o Cartel defrontava-se com o seu primeiro problema de monta, de natureza eminentemente política. Os conservadores, após o 11 de maio, não hesitaram em lançar retumbante campanha de descrédito do novo governo e de atemorização dos detentores de títulos públicos, realizando comícios e reverberando aos quatro cantos as propostas de consolidação forçada da dívida e de imposto sobre o capital, apoiadas abertamente pelos socialistas de Léon Blum e pelos radicais associados a Herriot. O jornal Les Temps, por exemplo, logo após as eleições, denunciava tratar-se o Cartel de "uma maioria gastadora" que necessitaria de vastos recursos para cobrir suas promessas sociais, cujo resultado seria um só: "Esse dinheiro que falta, ele [o Cartel] buscará nos novos impostos violentos e tirânicos, no confisco de capitais, das propriedades, das heranças, dos ganhos industriais e comerciais [...] Uma crise financeira sem precedentes é de se antecipar desde logo. O que será amanhã do crédito da França? Aonde irá parar o nosso franco?”. ${ }^{20}$

Para agravar a situação, Clémentel, ansioso por revelar as falhas da administração do Bloc National, faz publicar um inventário do endividamento público legado por Poincaré que, entretanto, tem por efeito somente alarmar o público. Além disso, o Partido Socialista não cessa de apregoar a necessidade de consolidação forçada dos bônus do Tesouro Nacional e de instauração de um imposto (prélèvement) sobre o capital. "Buscaremos o dinheiro onde ele se encontra", proclamou então o deputado socialista Pierre Renaudel. ${ }^{21}$ Entre um amplo contingente de moderados do Cartel, contudo, vicejava firme resistência às medidas mais extremas de resolução do impasse financeiro, epicentro da aguda sismologia política do período. O próprio Clémentel e, mais tarde, Raoul Péret, ministro das finanças do nono gabinete Briand, viriam a renunciar em virtude de sua oposição às iniciativas capazes de atentar contra a inviolabilidade do capital dos investidores. Como bem sumarizou um historiador daqueles dias:

Todos os sucessivos governos Briand postavam-se diante dessa contradição: a Câmara recusava-se a votar, sob a influência dos socialistas, as medidas de inspiração forçosamente liberal que lhes eram apresentadas como as únicas capazes de restabelecer a "confiança". E, de outra parte, a Gauche Radicale, grupo determinante dessa Assembleia instável, não concedia jamais seu apoio às medidas de espírito socialista propostas pela Comissão de Finanças. A situação não dispunha de uma saída parlamentar. Os homens do Cartel não podiam adotar a política da confiança sem romper a sua maioria. Quando eles recuperavam a maioria, perdiam imediatamente a "confiança". ${ }^{22}$

$\mathrm{Na}$ base do embate político jazia ainda uma contenda permanente entre o Tesouro e o Banco da França sobre os rumos da política econômica do país. Isso porque a legislação francesa estabelecia um duplo teto (double plafond) para a emissão da moeda nacional: o primeiro limitando a circulação monetária no conjunto da economia e o segundo regulando os adiantamentos do Banco da França ao Tesouro. Em 1920, Frédéric François-Marsal, então ministro das finanças do gabinete Millerand, faz aprovar um acordo que levaria o seu nome estipulando o reembolso anual de 2 bilhôes de francos por parte do Tesouro ao Banco da França. Essa convenção, de fato, apenas regulamentava uma anterior, de 21 de setembro de 1914, firmada pelo ministro das finanças Alexandre Ribot e pelo diretor geral do Banco da França à época, Georges Pallain, a qual prescrevia que o Estado, no menor tempo possível, deveria resgatar os adiantamentos extraordinários de guerra concedidos pelo Banco da França e que, em 1920, totalizavam 27 bilhóes (Tabela 1). Subjacente a tal medida encontrava-se a crença na retomada, adiante, da conversibilidade ouro do franco prevalecente no pré-guerra, como sucedera em 1878, quando o governo logrou liquidar integralmente os seus débitos com o Banco da França. De acordo com a visão do ministro Ribot: "O crédito do Banco e o do Estado não devem se confundir; e no momento em que uma crise como a atual [a guerra] obriga o Estado a recorrer ao Banco, ele não pode fazê-lo senão com a condição de retornar o mais cedo possível à ordem habitual”. ${ }^{23}$

A convenção François-Marsal haveria de gerar todo o tipo de dificuldades para o Tesouro francês. Apenas em 1921, ano de crise econômica internacional, seria possível ao governo honrar integralmente 
o pagamento estipulado em virtude de os novos títulos públicos apresentarem-se ainda como um ativo interessante aos investidores. A situação, contudo, sofreria inflexão logo no ano seguinte, quando a retomada da atividade econômica passou a dificultar o refinanciamento da dívida pública junto aos bancos e aos particulares em virtude dos requerimentos de moeda por parte do setor privado. De uma perspectiva prática, os títulos públicos em circulação poderiam ser interpretados como depósitos a curto prazo dos investidores sob a responsabilidade do Tesouro e que, sem aviso prévio, estariam sujeitos a serem convertidos em moeda conforme as necessidades do mundo dos negócios ou o estado de confiança dos credores. Esse fato, quando sobreposto aos vultosos requerimentos de fundos privados pelo governo, deixava claro aos administradores das contas públicas a fragilidade da política econômica em curso associando déficits fiscais com restrição monetária. Jean Parmentier, diretor do Mouvement des Fonds (19211923), instância administrativa do Tesouro, em carta ao ministro de Lasteyrie, no ano de 1922, já alertava para os graves perigos decorrentes do volumoso endividamento público de curto prazo:

A verdade é que os detentores atuais dos bônus do Tesouro consideram-nos como um capital do qual eles decidiram não se desfazer, em circunstâncias normais [...] Enquanto a confiança restar intacta, essa situação não terá razão para se modificar; mas se a confiança da população e do estrangeiro sobre o futuro do franco vier a ser abalada, as mais graves consequências seguirão fatalmente. Os detentores de francos, com uma rapidez acrescida pelo exemplo da Alemanha, buscarão a todo custo se desembaraçar de uma moeda da qual o valor lhes parece diminuir constantemente. ${ }^{24}$

Para evitar esse cenário, Parmentier recomendava cortes impiedosos nas despesas armamentistas, de reconstrução e até mesmo nos pagamentos de pensões aos ex-combatentes. Ele, no entanto, se insurgia também contra a convenção François-Marsal por recear que um quadro provável de depreciação do franco viesse a exigir taxas de juros cada vez mais elevadas para a rolagem da dívida pública, comprometendo a execução financeira do Tesouro de maneira irremediável apenas para honrar o acordo com o Banco da França. ${ }^{25}$ Em março de 1923, Parmentier é sucedido por Pierre de Moüy, que, em seguida, reporta mais uma vez ao ministro das finanças a incongruência da Convenção de 1920: "Quero acreditar, de resto, que o Banco da França não deixará de perceber como será imprudente prosseguir, nas atuais circunstâncias, com uma política de deflação concebida num tempo em que se podiam formar esperanças sobre a evolução financeira que os eventos infelizmente fizeram por desmentir." ${ }^{26}$ Enquanto, prevalecesse a crença num resgate substancial das reparações alemãs, a estratégia deflacionária parecia a única alternativa viável para a política monetária nacional. Ademais, a lembrança ainda que longínqua dos Assignats, reavivada pela hiperinflação do Reischmark, fazia por converter em heresia qualquer insinuação em favor de uma elevação do plafond do Estado e, por conseguinte, de se implementar uma oferta monetária administrada. Assim, Robineau considerava a emissão de bilhetes por conta dos adiantamentos ao governo como inteiramente artificial e efetivada em prejuízo das necessidades legítimas do comércio, podendo solapar a confiança do público indispensável à solidez da moeda. A liquidação do débito do Estado com o Banco da França permitiria ainda, segundo o diretor geral, que a instituição pudesse ampará-lo novamente no futuro sem o risco de catástrofe monetária. ${ }^{27}$

\section{Respondendo ao fogo: as novas bases da estabilização}

Quando Briand então se pôs a refletir sobre o nome mais indicado para a condução das finanças do país, em julho de 1926, a situação aproximava-se do seu limite. As reparações alemãs, finalmente equacionadas pelo Plano Dawes, revelavam-se insuficientes para cobrir a dívida pública acumulada em seu nome. Além disso, a Inglaterra já retornara ao padrão-ouro, com a agressiva diplomacia da esterlina, conduzida pelo Presidente do Banco da Inglaterra, Montagu Norman, exercendo forte pressão nos mercados financeiros continentais. ${ }^{28}$ Briand, por certo, não retomaria as rédeas do governo, sabedor que o ambiente parlamentar mostrara-se repetidamente ineficaz para levar avante uma estratégia definitiva de 
saneamento da moeda nacional. E quem teve plena consciência dessa impossibilidade foi o seu ex-ministro Péret que, antes de se demitir, constituiu, em $1^{\circ}$ de junho de 1926, uma Comissão de Especialistas (Comité d'Experts) encarregada de elaborar um plano de estabilização do franco. ${ }^{29}$ Nesse instante, começava a se erigir uma alternativa à política econômica até então dominada pelo consenso deflacionário-revalorizador emanado do Banco da França. ${ }^{30}$

A Comissão de Especialistas trabalharia em ritmo acelerado, e, em 4 de julho, o seu relatório final é publicado, propugnando seis medidas principais voltadas à estabilização monetária, a saber: (1) equilíbrio do balanço de pagamentos mediante a contenção da evasão de divisas, o levantamento de créditos estrangeiros e o retorno progressivo dos capitais expatriados; (2) equilíbrio absoluto no orçamento público, envolvendo economia estrita nas despesas e elevação nas receitas, especialmente nos impostos indiretos de modo a não comprometer a poupança nacional; (3) alívio do Tesouro, instituindo-se uma Caixa de Amortização para a gestão e o resgate da dívida flutuante; (4) negociação definitiva das dívidas de guerra, especialmente com a Inglaterra e os Estados Unidos; (5) adaptação da economia do país às novas condições dadas pelo fim da inflação e por um aumento temporário da taxa de juros, e (6) constituição de um lastro em ouro e de uma carteira comercial no banco de emissão de modo a sustentar a conversibilidade dos bilhetes. ${ }^{31}$ Logo ao início do relatório, não obstante, desafiando o consenso prevalecente no país, ${ }^{32}$ os especialistas deixavam claro que a abolição do curso forçado do franco não significaria o retorno à paridade do pré-guerra, já que as suas recomendações implicavam apenas uma definição legal do novo valor em ouro da moeda. A posição unânime dos signatários do relatório surge numa passagem breve, mas contundente, a qual vale a pena reproduzir:

A revalorização integral do franco é atualmente uma quimera, pois ela supõe uma deflação contínua e sistemática, ruinosa para os contribuintes, que serão esmagados pelo fardo de uma dívida pública representando em valor nominal a totalidade da fortuna francesa, ruinosa para a indústria, o comércio e a agricultura, que não poderão suportar nem a redução indefinida dos preços, nem as consequências dos compromissos contratados desde o início da depreciação do franco. [...] Os ajustamentos incessantes dos preços, dos salários, dos juros, serão motivo de crises econômicas continuadas e tão graves que a vida social em tais condições será constantemente subvertida [...] Com efeito, na vida econômica moderna, os contratos se renovam, os títulos se trocam e os bens se transmitem tão rapidamente que se torna inútil esperar que a revalorização prolongada do franco venha a reparar as injustiças. ${ }^{33}$

Desse modo, as linhas gerais da estabilização monetária na França estavam colocadas em novas bases, deveras distintas daquelas fornecidas pela Convenção François-Marsal, e que prenunciavam a investida final do Cartel contra a cidadela do Banco da França. Mas, se a defesa da revalorização por parte da instituição parecia o motivo de fundo para o ataque, havia ainda duas razões de ordem prática para tanto. Em primeiro lugar, o Banco da França, quando requisitado pelo Cartel, recusara-se em diversas oportunidades a utilizar o seu estoque de ouro para interferir no mercado de câmbio contra a depreciação do franco. A primeira vez, em março de 1925, quando instado por Clémentel e, após, em maio de 1926, quando solicitado insistentemente por Péret e pelo próprio Briand. Como justificou Robineau na ocasião: "O Conselho Geral resta convencido que após uma melhora momentânea que durará enquanto o câmbio for fornecido a bom preço mediante a venda do lastro supremo dos bilhetes do Banco, resultará finalmente para o franco um prejuízo ainda mais profundo e irreparável.”34 Já o barão de Rotschild, um dos mais poderosos membros do Conselho, manifestou-se publicamente sustentando que nenhuma ação sobre o mercado de divisas obteria sucesso sem um governo conservador no poder. ${ }^{35} \mathrm{O}$ argumento do diretor geral, é preciso admitir, apresentava-se correto ao esclarecer que a depreciação, em verdade, não resultava de especulação externa, mas do descrédito do Tesouro junto ao público em geral, sendo inútil o lançamento indiscriminado das reservas bancárias no mercado em tais condiçôes. Para os integrantes do Cartel, todavia, as coisas soavam diferentes. Isso porque o mesmo Robineau colaborara ativamente com Poincaré na erradicação da crise financeira do início de 1924, ao 
ceder as reservas áureas como garantia de um empréstimo externo junto à casa dos Morgan e ao centralizar no Banco da França as operaçôes diárias sobre o mercado de câmbio. ${ }^{36}$

Em segundo lugar, remanescia entre os cartelistas a lembrança amarga do escândalo dos relatórios falsos do Banco da França, divulgados ao público em 7 de abril de 1925, e que conduziriam à queda do primeiro gabinete Herriot diante do Senado, quatro dias depois, por alegada cumplicidade com o esquema. A questão, em suma, residia no fato de que, diante do seu progressivo embaraço fiscal, o Tesouro terminava por recorrer a empréstimos de curto prazo fornecidos pelas instituiçôes financeiras de Paris. Estas, por sua vez, redescontavam os títulos públicos recebidos como garantia junto ao Banco da França que, assim, indiretamente, fazia por elevar a emissão monetária, até que o teto global de 41 bilhões de francos veio a ser ultrapassado em outubro de 1924. A falsificação dos relatórios semanais da circulação fiduciária, declarada aquém do plafond, envolvia a ampliação indevida das deduçôes relativas às cédulas em trânsito entre a sede do Banco e as suas sucursais, bem como a antecipação das somas em dinheiro a serem destruídas, mas que ainda se encontravam nos caixas da instituição. ${ }^{37}$

A fraude foi descoberta pelo subdiretor, Omer Leclerc, em outubro de 1924, que comunicou a irregularidade imediatamente a Clémentel. O diretor geral Robineau e o premier Herriot, porém julgaram oportuno manter o problema no limbo durante alguns meses na esperança de que medidas financeiras ulteriores do Tesouro viessem a sanar a questão. François de Wendel, industrial, deputado conservador e membro do Conselho Geral, no entanto, pressionaria o Banco da França a revelar o subterfúgio, além de articular politicamente para que o gabinete fosse deposto, como viria de fato a ocorrer. A divulgação tardia do ardil contábil utilizado pelo Banco da França daria novo e definitivo impulso à fuga da moeda nacional, agravando sensivelmente a crise financeira do país.

Herriot, em suas memórias, Jadis, ${ }^{38}$ comenta sobre o assunto que a posição intransigente por ele adotada em favor da revalorização do franco tratava-se de uma questão de Estado, porquanto qualquer iniciativa no sentido de ampliar os adiantamentos ao Tesouro, como requisitado várias vezes pelo diretor de Moüy, seria interpretada pelos inimigos do país como sinal de fraqueza do governo. Além do mais, as dificuldades financeiras de seu gabinete teriam advindo do caráter excepcional da dívida de curto prazo construída pelos governos anteriores, à qual ele buscara unicamente honrar em conformidade com as restrições de caixa do Tesouro. Por fim, sobre os falsos relatórios do Banco da França, Herriot explica que seguira apenas o exemplo de Poincaré, à época do Bloc National, ao tomar recursos a curto prazo junto ao sistema bancário privado, tendo por isso sido injustamente vitimado pela ditadura do dinheiro: "Por diversas vezes, dirigi-me a meus adversários rogando a eles para não se vingarem sobre a França por sua derrota política. Eles se mostraram intransigentes." 39

Tabela 1. Principais indicadores fiscais e monetários: França, 1919-1928 (valores nominais em bilhôes de francos)

\begin{tabular}{|c|c|c|c|c|c|c|c|}
\hline & $(1)$ & $(2)$ & $(3)$ & $(4)$ & $(5)$ & $(6)$ & $(7)$ \\
\hline Anos & Receitas & Despesas & Saldo & Dívida & Dívida & Adiant. & Circulação \\
\hline & & & & a Termo & Flutuante & BF & Total \\
\hline 1919 & 13 & 40 & -27 & 98 & 43 & 25 & 37 \\
\hline 1920 & 23 & 40 & -17 & 103 & 79 & 27 & 38 \\
\hline 1921 & 24 & 33 & -9 & 136 & 86 & 24 & 37 \\
\hline 1922 & 35 & 45 & -10 & 148 & 87 & 23 & 37 \\
\hline 1923 & 26 & 39 & -13 & 161 & 89 & 23 & 39 \\
\hline 1924 & 35 & 43 & -7 & 184 & 87 & 22 & 41 \\
\hline 1925 & 35 & 36 & -2 & 193 & 87 & 36 & 51 \\
\hline 1926 & 43 & 42 & 1 & 199 & 93 & 34 & 53 \\
\hline 1927 & 46 & 45 & 1 & 197 & 93 & 24 & 57 \\
\hline 1928 & 48 & 44 & 4 & 193 & 80 & 3 & 62 \\
\hline
\end{tabular}

Fontes: (1)-(3) Histoire politique de la Troisième République, de Édouard Bonnefous (1960, T. 4, Annexe II); (4)-(7) Cent ans de République, de Jacques Chastenet (T. 5, p. 259-260). Obs.: (4) inclui a dívida perpétua;

(6) adiantamentos do Banco da França. 
Os episódios descritos contrapondo o Banco da França ao Cartel acabariam por selar a sorte da pasta das finanças na complexa equação política de Briand. Em vista das novas condições, mais precisamente, da existência da Comissão de Especialistas preconizando a desvalorização e condenando a passividade do Banco da França perante a crise do câmbio, o cargo demandava não apenas um homem capaz de se alinhar à nova abordagem técnica a ser aplicada ao problema financeiro do país. Ele, em acréscimo, precisaria ser audacioso, ainda que controverso, disposto a seguir o caminho sem volta, isto é, a cruzar o Rubicon e a limpar de uma vez por todas "as cavalariças de Augias". ${ }^{40}$ É difícil não imaginar a satisfação do renegado Caillaux quando, em 25 de junho de 1926, dois dias após assumir a pasta das finanças e a vice-presidência do Conselho, convoca Robineau ao seu gabinete e lhe informa da decisão por ele acalentada desde o ano anterior, ao tempo de Painlevé: "Meu caro Diretor Geral, por diversas vezes você manifestou a intenção de descansar. O governo hoje se encontra em condição de lhe indicar um sucessor. Ele será M. Moreau, cujo nome aparecerá amanhã no jornal l'Officiel."41

\section{Moreau, Poincaré e a emergência monetária}

Avisado por Caillaux de sua posse iminente no Banco da França, Emile Moreau ${ }^{42}$ recebe a notícia com satisfação, seja pelo fato de haver sido relegado ao ostracismo por vinte anos na direção do Banco da Argélia, seja por julgar Robineau um diretor débil, manipulado por Aupetit e incapaz de preservar a autonomia do Banco da França diante das ingerências políticas. Logo que assume a sua nova função, Moureau procura o segundo subdiretor Leclerc a fim de se inteirar do mecanismo de falsificação dos relatórios da circulação fiduciária. Após garantir a ele promoção para o posto de primeiro subdiretor, uma vez que Ernest-Picard é removido para o Banco da Argélia, Moreau, como prometera a Caillaux, demite o secretário-geral Aupetit que, inconformado, precisa ser retirado de seu escritório à força por Leclerc. Charles Rist, professor da Faculdade de Direito de Paris, é convidado para o cargo de segundo subdiretor, evidenciando uma tomada de assalto planejada da cúpula do Banco da França pela Comissão de Especialistas. Leclerc fica responsável pela supervisão das operações de desconto e dos contenciosos do Banco e Rist pelo acompanhamento das questôes relativas ao câmbio e à moeda. Ainda, o funcionário de carreira Strohl é indicado novo secretário-geral, enquanto o jovem e talentoso Pierre Quesnay é recrutado da seção financeira da Liga das Naçóes, onde trabalhara durante quatro anos na estabilização da moeda austríaca, para atuar como chefe de gabinete do novo diretor geral.

Enquanto encaminha as primeiras providências administrativas, ${ }^{43}$ Moreau demonstra contentamento com a publicação do relatório dos experts: "Pela primeira vez", anota ele na ocasiāo, "retira-se o problema da moeda e das finanças públicas da arena política para colocá-lo no terreno técnico". ${ }^{44}$ Mas, logo a seguir, ele mesmo haveria de reconduzir os problemas financeiros ao terreno pantanoso da política. Isso porque sua apreensão no tocante aos destinos do franco cresce com rapidez, especialmente em virtude das notícias que recebe sobre a fragilidade da posição de Caillaux, com quem se encontra regularmente. Consumada a queda de Briand, não lhe agradam de modo algum a ação de Herriot no episódio e o consequente agravamento da fuga dos capitais, quando chega a ser interrompida a transmissão radiofônica das notícias financeiras.

No dia 20 de julho, pela manhã, o novo responsável pelas finanças, de Monzie, convoca Moreau ao ministério, onde este se depara com o ministro e seus auxiliares desesperados perante a situação financeira do Tesouro, responsabilizando Caillaux pela catástrofe e ameaçando consolidar a dívida de curto prazo, além de anunciar uma moratória dos pagamentos, medidas que Moreau repudia como extremamente perigosas. Nova reunião ocorre à noite com as presenças do diretor geral, do deputado Louis Loucher e do ministro de Monzie, acompanhado por dois assessores. Segundo Moreau, seus interlocutores sequer disfarçavam o estado de absoluto desamparo, ansiosos por abandonar o poder sob qualquer pretexto. O diretor geral não perde tempo e avisa-os que caso o Parlamento não autorize o Banco a comprar os dólares do empréstimo Morgan, ${ }^{45}$ cortará os créditos do Tesouro no dia seguinte, suspendendo 
inclusive os pagamentos dos salários e dos fornecedores. Moreau, ao sair do encontro, informa sua decisão pessoalmente a Clément Moret, diretor do Mouvement des Fonds e, mais tarde, ao próprio Presidente Doumergue. A advertência, não por acidente, serviria de poderosa munição à oposição conservadora no parlamento. No dia seguinte, 21 de julho, a comoção pública é angustiante e compartilhada por Moreau: "A alta dos valores mobiliários, no mercado de Paris", escreve ele, "tem sido desenfreada. Relatam-me que o pânico monetário se espalha por toda a França e cresce de hora em hora. Ninguém mais quer saber dos bilhetes. É um salve-se quem puder geral". ${ }^{46}$ Ao tomar conhecimento que o Presidente da Câmara fora batido em seu próprio território, o diretor geral não oculta o regozijo com o desfecho: "O Ministério Herriot é derrubado durante a noite. Ele morre sem haver nascido [...] A atitude firme do Banco da França, obrigando o governo a revelar publicamente a situação extrema do Tesouro e impedindo-o, para remediá-la, de recorrer a subterfúgios ilegais, contribuiu deveras para esse resultado." ${ }^{7}$

Quando então Poincaré adentra a Câmara dos Deputados para apresentar o seu ministério de Union Nationale, em 27 de julho de 1926, o deputado comunista Marcel Cachin exclama ao novo premier: "Nós não o vemos senão em tempos de infortúnio!" 48 O que deveria ser um insulto viria a ser considerado, por vias transversas, a primeira manifestação de reconhecimento do experiente homem de Estado como o verdadeiro salvador (sauveter) da economia nacional. E, com efeito, o simples anúncio da convocação de Poincaré para a presidência do conselho tem por resultado imediato reverter de maneira espantosa a depreciação do franco (Figura 1), evidenciando que a crise financeira, se não poderia ser resolvida pela política, como pensava Moreau, tampouco seria debelada sem ela. Mas Poincaré, apesar de ter sido ministro das finanças por um breve período no pré-guerra - 30 de maio 1894 a 27 de janeiro de 1895 -, detinha pouco conhecimento na área, seu grande trunfo residindo na circunstância de haver sobrepujado os especuladores externos durante a crise financeira de março de $1924 .{ }^{49}$

Ao assumir a presidência do conselho e a pasta das finanças, Poincaré demonstra extrema cautela e grande hesitação em diversos momentos, particularmente no tocante ao nível da estabilização e à estratégia geral para implementá-la. Inimigo declarado de Caillaux e dos que lhe eram próximos, já na primeira reunião com Moreau, em 24 de julho de 1926, demonstra franca hostilidade em relação ao diretor geral, criticando o antigo ministro e informando não estar disposto a ratificar o acordo CaillauxChurchill sobre a dívida de guerra da França com a Inglaterra. ${ }^{50}$ No segundo encontro, dois dias depois, Poincaré procura subjugar Moreau ao informar-lhe, num ambiente tenso, seu propósito de negociar um empréstimo com os bancos privados em troca de títulos do Tesouro a serem redescontados junto ao Banco da França. Este, contudo, era o mecanismo utilizado por Clémentel e que levara à ultrapassagem do teto de emissão, contra o qual Moureau se insurge de forma vigorosa por constituir-se, em suas palavras, numa verdadeira inflação. Diante do impasse, o diretor geral se mostra firme perante o presidente do conselho. Ou, como relatado nos Souvenirs:

O debate se anima. Declaro a Poincaré que o Banco da França não poderá realizar tal operação a não ser que os estabelecimentos de crédito ofereçam, em troca do dinheiro, não os bônus do Tesouro, mas os títulos comerciais estatutários. O presidente do Conselho parece furioso.

A operação que proponho foi feita várias vezes em 1923 e 1924 por seu predecessor, M. Robineau, sem a menor dificuldade. Se você não consentir, chamarei M. Robineau...

Dissimulo minha irritação e, friamente, levanto-me e digo a Poincaré:

Monsieur Presidente, você teve uma excelente ideia. Chame M. Robineau. Eu me despeço... Boa noite... E me dirijo à porta.

Mas Poincaré, subitamente, se acalma e me chama, me faz tomar assento novamente e diz que me conhece há muito tempo e que tem grande estima por mim. ${ }^{51}$

Apesar de ceder, no dia seguinte, à condição exigida por Moreau, Poincaré evidencia que, naquele momento, ainda não se definira pelo caminho a seguir, lançando mão de um expediente que se revelara de todo ruinoso na evolução das finanças do país. Esse, em verdade, tinha sido o método por meio 
do qual o Banco da França perdera, de uma vez por todas, o comando sobre o volume de seus bilhetes. Como viria a assinalar logo adiante o perspicaz Quesnay: "[...] o banco não controla pouco mais de $10 \%$ da circulação, isto é, a parte representada pelos efeitos do comércio em seu balanço. Ele não pode agir por sua política de crédito senão sobre essa parcela irrisória de suas emissões." 52 Ademais, a manifestação de Poincaré durante a discussão parece não deixar dúvidas que a administração anterior do Banco da França dispunha de autonomia mínima diante do Tesouro, ao menos durante os anos do Bloc National, sendo lícito inferir-se que os relatórios falsos sobre a circulação monetária não teriam sido iniciados por Aupetit sem algum tipo de anuência prévia do então presidente do conselho. ${ }^{53}$

Num encontro em 30 de julho, Poincaré recebe Moureau de forma amigável e indica estar disposto a aplicar o Plano dos Especialistas, elevando os impostos não só a fim de equilibrar o orçamento, mas também visando prover de recursos uma Caixa de Amortização dos bônus de curto prazo, a ser criada com garantias constitucionais. Além disso, o primeiro-ministro afirma sua disposição em ratificar os acordos da dívida com os Estados Unidos e a Inglaterra de modo a obter empréstimos externos para servirem de lastro ao franco, cuja emissão seria gerida pelo Banco da França com total independência. ${ }^{54}$ Moreau, satisfeito, propõe a elaboração de uma lei permitindo ao Banco a compra e venda de moedas de ouro e de divisas ao valor corrente, com os bilhetes assim emitidos permanecendo fora do plafond, no que obtém aprovação do primeiro-ministro. Dois dias depois, contudo, Poincaré convoca Moureau e lhe informa ainda relutar sobre o aval para compra de moedas de ouro e de divisas por parte do Banco, possivelmente sob influência do barão de Rotschild. ${ }^{55}$

Em 3 de agosto, Poincaré convoca a Comissão de Especialistas para agradecer pelo trabalho realizado, mas sem se comprometer com quaisquer das iniciativas que assegurara a Moreau implementar. $\mathrm{O}$ diretor geral, um tanto surpreso com a indecisão do governo, reúne-se mais tarde com Quesnay e elabora um plano próprio de estabilização, abrangendo os seguintes pontos: (1) o processo deveria ser comandado pelo Banco da França; (2) os dirigentes do Banco permaneceriam inamovíveis; (3) a taxa de câmbio do franco viria a ser definida pelo governo e pelo Banco da França; (4) as reservas seriam constituídas por divisas fornecidas pelo Tesouro, num mínimo de 400 milhões de dólares, por empréstimos do Banco da França junto a outros bancos centrais e por fundos externos obtidos por grandes empreendimentos franceses; (5) congelamento do crédito e, por fim, (6) reavaliação do encaixe metálico junto ao Banco da França. ${ }^{56}$ Poincaré, no dia seguinte, não se entusiasma pelas novas propostas e defende a revalorização, para desalento de Moreau. Na verdade, ao ministro das finanças não faltavam razóes de peso para ser paciente e deixar se encorpar a alta no valor do franco, como ressaltou um estudioso do período:

[A Poincaré] repugnava a ideia de despojar definitivamente os patriotas que, durante a guerra, haviam cedido seu ouro por bilhetes, assim como os pequenos rentistas, os pensionistas, os portadores de valores com renda fixa, numa palavra, todos aqueles que, ou mesmo os seus pais, tinham depositado confiança na honestidade do Estado francês. Seu instinto lhe empurra, apesar das objeçōes, em direção ao retorno do franco germinal, aquele que, multiplicado por cinco, era suficiente para comprar um dólar e, multiplicado por vinte e cinco, para comprar uma libra. ${ }^{57}$

\section{O Tesouro, o Banco da França e o embate final sobre a estabilização}

À medida que os dias escoam, prossegue a entrada de divisas e a recuperação do franco. O Tesouro adquire grandes quantidades de moedas estrangeiras, mas logo percebe ser impossível dar conta do fluxo de repatriação dos capitais. Poincaré decide apoiar o projeto de Moreau e submete ao legislativo uma exposição de motivos permitindo ao Banco da França a compra de moedas de ouro e de divisas a preços de mercado. Em 6 de agosto, jornada decisiva, a Câmara dos Deputados aprova a criação da Caixa de Amortização e, na madrugada do dia 7 , as operações do Banco com ouro e moedas estrangeiras. A autorização, como assinalou o diretor geral, representava o abandono oficial e definitivo da retomada da paridade do pré-guerra. Em tais condiçóes, portanto, a nova taxa à qual o franco deveria ser estabilizado pas- 
sava ao centro do debate. Numa de suas entrevistas com Poincaré para tratar o assunto das divisas, Moreau delimita claramente a sua posição: "Aproveito a visita para chamar a atenção de Poincaré sobre os graves riscos econômicos que uma valorização muito rápida e considerável do franco virá a produzir. Presto-lhe conta da situação difícil na qual se encontrariam [...] certo número de empreendimentos franceses". ${ }^{8}$

Poincaré, contudo, insiste na necessidade de valorização da moeda, atribuindo as dificuldades financeiras do país aos especuladores externos. Em 18 de agosto, Leclerc informa a Moreau que o primeiroministro, privadamente, demonstra grande animosidade contra a Comissão de Especialistas e a nova direção do Banco da França, reunindo-se frequentemente com Robineau, Aupetit e o barão Rotschild. ${ }^{59}$ Posto que Poincaré se mantém indefinido sobre o momento e o nível da estabilização, a aquisição de divisas para a constituição de um lastro adequado para sustentar o franco, como permitido pela lei de 7 de agosto, envolveria risco extremamente elevado para o Banco da França. Isso porque, prevalecendo a tese de revalorização da moeda propalada pelos conselheiros de Poincaré, as perdas associadas à diferença entre o preço de aquisição das divisas e o seu valor contábil final seriam lançadas integralmente no balanço da instituição. Não obstante, Poincaré e Moret, diretor do Mouvement des Fonds, pressionam Moreau para iniciar de imediato a intervenção no mercado cambial a fim de livrar o ministério das finanças dos prejuízos envolvidos nas operações. ${ }^{60} \mathrm{O}$ diretor geral, contudo, não recua e registra, em 10 de setembro, sua posição final: "Com efeito, se, como quer M. Poincaré, aceitarmos endossar as perdas resultantes de nossa intervenção sobre o câmbio, terminaremos por violar a lei que interdita o Banco da França de efetivar adiantamentos ao Tesouro além do máximo denominado plafond. M. Strohl é encarregado de redigir o artigo 3 tendo em conta essa consideração." 11

Em 16 de setembro, Poincaré finalmente aceita as condiçōes estabelecidas por Moreau para evitar prejuízos ao Banco. Segundo a redação final do termo de compromisso, ao encerramento de cada trimestre seria reavaliado o valor do estoque de divisas segundo a média do período. Apurando-se ganho, o mesmo viria a ser creditado numa conta provisória e, após, debitado dos adiantamentos do governo junto ao Banco. No caso de perdas superiores a uma quarta parte do valor do estoque detido pela instituição, o Tesouro deveria adquirir as divisas que necessitasse para os seus pagamentos externos ao preço original pago pelo Banco até a recondução do saldo devedor ao limite de segurança indicado. No mesmo dia, a convenção é aprovada por unanimidade pelo Conselho Geral, o que reforça a posição do diretor geral diante de seus membros. Moreau prossegue então com os preparativos para a instalação do serviço de câmbio da instituição, a ser comandado pelo caixa principal Pelet e pelo corretor Verdier, cedido pelo Credit Lyonnais.

O franco, nesse meio tempo, segue se valorizando, e, enquanto Poincaré pressiona para o início das operaçôes cambiais, Rist e Quesnay, temendo os efeitos da situação sobre o desempenho da economia, insistem com Moreau para estabilizar a moeda sem mais demoras. Mas o diretor geral mostra-se prudente e, de resto, pouco satisfeito com as garantias recebidas. Isso porque, em primeiro lugar, permanece convencido que Poincaré busca a revalorização, mas deixando a cargo do Banco a tarefa de acumular lastro suficiente de divisas para atender as necessidades ordinárias do Tesouro e, ao mesmo tempo, debelar eventual nova onda de desvalorização. Se, como receava o diretor geral, a revalorização terminasse por ocorrer, o Banco contabilizaria grande prejuízo. Ou, como ele próprio escreveu em relação ao assunto: "Tais perdas, é certo, são garantidas pelo Tesouro em virtude das leis de 7 de agosto e da convenção de 16 de setembro. Mas como o Tesouro é praticamente insolvente, sua garantia de nada vale."62 De outra parte, sem que Poincaré definisse o nível final da estabilização, Moreau decide se manter inflexível em sua recusa de intervir no mercado cambial, temeroso de que, ao frear a valorização da moeda, viesse a ser deflagrada nova investida dos especuladores em favor da desvalorização, quadro que encontraria o Banco da França desprovido de reservas suficientes para estancar o processo. ${ }^{63} \mathrm{Com}$ vistas a superar o problema, Moreau não vê outra saída que não o recurso aos empréstimos externos, obstruída, contudo, pela falta de aprovação dos acordos sobre as dívidas aliadas. 
Em 23 de setembro, Poincaré, por seu turno, demanda formalmente ao Banco da França que explicite as condições para que a instituição venha a intervir no mercado cambial. Moreau protela deliberadamente a resposta. Em conversa com o barão Rotschild, no dia 6 de agosto, de quem pouco a pouco se aproxima, o diretor geral e o barão concordam que, doravante, o Banco deverá ter a garantia de emitir bilhetes apenas para o desconto de papéis comerciais ou para a compra de ouro, de moedas de ouro ou de divisas; além disso, que o orçamento público esteja equilibrado, a dívida flutuante consolidada e grande parte dos adiantamentos ao governo reembolsada, assegurada, por fim, absoluta independência do Banco em relação ao Estado. As propostas são submetidas ao Conselho Geral no dia seguinte e aprovadas por unanimidade. ${ }^{64} \mathrm{O}$ serviço de câmbio do Banco, não obstante, começa a operar em 16 de outubro, mas em escala modesta e unicamente para atender às necessidades do Tesouro. A pressão, todavia, continua, e, no dia 20 de outubro, Moret e Barnaud, do ministério das finanças, reclamam de Moreau ação incisiva para conter a especulação a favor da alta do franco. O diretor geral não cede e vai ao encontro de Poincaré que, mais uma vez, tenta lhe vergar:

Se você não quiser constituir um aprovisionamento de divisas pelas compras diretas do Banco da França no mercado cambial, convocarei o Conselho Geral diante do Presidente da República, ameaça Poincaré.

Mantenho a calma e respondo-lhe:

Senhor Presidente, é preciso definir desde logo se o Governo deseja que o Banco de Emissão seja um estabelecimento privado ou um Banco de Estado. No primeiro caso, é imperativo respeitar a sua independência. No segundo, é mister reformá-lo por uma lei, o que será fácil, pois o diretor geral, os subdiretores e o Conselho Geral estão dispostos a se retirar para deixar o campo livre.

M. Poincaré me declara ser partidário de um banco de emissão privado.

Eu também, Senhor Presidente, lhe respondo, mas nesse caso é preciso deixar tranquilo o Conselho Geral e não mais procurar molestá-lo. ${ }^{65}$

Ao final de outubro, todavia, começam a espocar os sinais de que a valorização da moeda passa a repercutir de forma negativa na economia. Mais exatamente, no dia 29, Rist adverte Moreau sobre a existência de um consórcio internacional para especular com a alta do franco, cujos efeitos perversos já estariam a se manifestar na indústria e no desemprego, o que poderia transbordar em sérios problemas sociais. Moret, de sua parte, em 3 de novembro, comunica já haver adquirido todas as divisas necessárias para os pagamentos a vencer no estrangeiro durante o ano seguinte. Nessa mesma reunião, o diretor geral e o ministro das finanças parecem se aproximar de uma abordagem comum à estabilização. Como consta na entrada pertinente dos diários:

Definimos, M. Poincaré e eu, algumas das condições preliminares da estabilização: em primeiro lugar, ratificação dos acordos de Washington, ou ao menos uma distensão franco-americana a esse respeito - $\mathrm{M}$. Poincaré imagina, com efeito, que o concurso moral dos Estados Unidos nos será indispensável; vou mais longe e adiciono que a sua ajuda material será igualmente necessária. Em segundo lugar, se ele não conseguir consolidar inteiramente a dívida flutuante, será preciso ao menos prover a Caixa de Amortização de uma larga reserva para deixar o Tesouro e o Banco da França ao abrigo de demandas massivas de reembolso dos Bônus da Defesa Nacional. Enfim, quando por mim questionado, M. Poincaré reconhece formalmente que será necessário reembolsar, ao menos parcialmente, os adiantamentos concedidos ao Estado pelo Banco da França. ${ }^{66}$

Alguns dias depois, em 15 de novembro, Poincaré recebe a visita do ex-chanceler do Erário britânico, Reginald MacKenna, que lhe recomenda prudência na ratificação dos acordos das dívidas aliadas e perseverança na luta pela revalorização do franco. Os conselhos parecem ter surtido efeito e Moreau nota que Poincaré se mostra mais uma vez hesitante sobre a estabilização. No dia 19, o presidente da Câmara de Comércio de Auxerre, em visita ao Banco, explica a Moreau que na região em que reside o comércio e a indústria não poderão suportar a queda da libra abaixo de 125 francos, sem que uma grave crise venha a se instalar. ${ }^{67}$ Poincaré, novamente, pressiona o diretor geral a agir sobre o câmbio. Moreau 
sonda Verdier e Rist sobre a possibilidade de estancar a alta do franco, mas o primeiro desaconselha a iniciativa em vista da penúria de reservas do Banco, insuficientes para contrabalançar eventual movimento reverso de desvalorização da moeda. Moret, no dia 20 de novembro, demanda a Moreau convocar o Conselho Geral para decidir sobre a questão. A resposta do diretor geral é incisiva: "Vou ver M. Moret, na Rua Rivoli, e lhe transmito as preocupações de Verdier. Acrescento, com firmeza, que o Ministério das Finanças deve perder o hábito de tratar o Banco da França como uma de suas sucursais." ${ }^{8}$

Ao tempo em que cresce a pressão do Tesouro sobre o Banco, multiplicam-se os relatos das dificuldades enfrentadas pela economia. Em 8 de dezembro, o Conselheiro Laederich informa a Moreau as preocupações dos industriais contrários à valorização da moeda, acentuando que a oposição à escalada do câmbio cresce com rapidez. No dia 11, é a vez do industrial Abel Henry relatar os problemas da Societé Le Creusot que, por haver comprado libras em valor elevado, veio a registrar grandes perdas, tendo de suprimir a distribuição de dividendos. A seguir, em 14 de dezembro, Moreau toma conhecimento das dificuldades das empresas Citröen, Peugeot, Dion, Renault e Panhard, a primeira delas tendo solicitado ao Banco um empréstimo de emergência, negado pelo diretor geral. O Conselho Geral, no dia 16 de dezembro, por sugestão de Moreau, decide reduzir as taxas de juros em 1\% para o desconto de títulos, atitude reproduzida no mesmo dia pelo Conselho da Caixa de Amortização, que rebaixa em igual medida os rendimentos dos bônus sob sua responsabilidade. Em que pese a boa acolhida da iniciativa, a valorização do franco se acelera. As reservas em divisas do Banco, que em 15 de julho somavam 3,2 bilhões, atingem 6,4 bilhões em 16 de dezembro. ${ }^{69}$ Em 20 de dezembro, enfim, chega o ponto de virada. Barnaud, diretor-adjunto do Mouvement des Fonds, comunica por telefone a Moreau estar impotente para conter a avalanche de divisas. A cotação da libra cai abaixo de 120 francos. O diretor geral decide então que a hora havia chegado e, em seus próprios termos, se "arremessa à água" para resgatar o franco:

Embora sem autorização do Conselho Geral, tomo uma decisão que considero de interesse público. Para evitar um verdadeiro desastre econômico, impedir a paralisia de numerosos empreendimentos industriais e comerciais e o desemprego que se seguiria forçosamente, respondo a M. Barnaud que assumo o lugar do Tesouro no mercado de câmbio, rogando-lhe que me deixe manobrar como eu bem entender.

Ao desligar o telefone, reúno imediatamente em meu gabinete os senhores Leclerc, Rist, Verdier e Platet. Decidimos defender a qualquer custo o valor de 120 francos para a libra esterlina e montar uma barragem para impedir a alta ou a baixa de nossa moeda. M. Verdier se põe em ação imediatamente. Somos obrigados a comprar 930.000 libras para fazer remontar o valor da esterlina a 120 francos [...] À noite, M. Poincaré me faz transmitir os seus agradecimentos por meio de M. Moret. ${ }^{70}$

A estabilização de facto da moeda nacional, enfim, se materializava. A taxa média praticada pelo Banco da França passaria doravante a gravitar em torno de 124,25 francos por libra. A paridade de jure, porém, viria a ser oficializada apenas em 25 de junho de 1928, o franco four-sou. ${ }^{71} \mathrm{O}$ sucesso da estabilização promovida por Moreau redundaria em sensível melhora no seu relacionamento com Poincaré que, em janeiro de 1927, confere-lhe a comenda de Grande Oficial da Legião de Honra. ${ }^{72}$

Vale notar ainda que a atitude do primeiro-ministro em protelar ao máximo a homologação dos acordos das dívidas aliadas, tão lamentada por Moreau e julgada indispensável à estabilização do franco pelos experts, ${ }^{73}$ viria a se revelar, em última instância, assaz funcional para o objetivo da desvalorização. Isso porque, como visto, os empréstimos norte-americanos e a comercialização dos títulos de reparações da Alemanha nos Estados Unidos encontravam-se bloqueados por determinação expressa de Washington enquanto o acordo Mellon-Bérenger não fosse sancionado pela França. ${ }^{74}$ Os Souvenirs, por outro lado, evidenciam o cerco intermitente dos banqueiros norte-americanos ao diretor geral, prometendo-lhe acesso irrestrito a fundos privados norte-americanos, uma vez resolvido o problema da dívida de guerra. Eles chegaram mesmo a desembolsar grandes somas com a imprensa para facilitar a aprovação dos acordos, como confidenciou Poincaré a Moreau, certa ocasião. No dia 9 de outubro, consta o seguinte trecho nos diários do diretor geral: 
M. Rist me envia o coronel Laugan e M. Fisher, do banco Dillon Read, que me asseguram que o seu estabelecimento está à nossa disposição para, por seu intermédio, encontrarmos nos Estados Unidos todos os fundos que tenhamos necessidade visando a estabilização ou qualquer outro objetivo. ${ }^{75}$

Ora, tivesse Poincaré encaminhado com celeridade a ratificação do acordo de Washington, era de se prever a abertura das comportas aos recursos norte-americanos, cuja disponibilidade em largas quantias, considerando-se o retardo natural no processo político de estabilização, conduziriam a uma revalorização mais rápida e íngreme do franco do que aquela que veio efetivamente a prevalecer. ${ }^{76}$ Pode-se dizer, inclusive, que essa possibilidade não se tratava de mera conjectura, porquanto durante o ataque ao franco no inverno de 1924, a venda unicamente de uma parte dos dólares Morgan e das libras dos irmãos Lazard tiveram precisamente esse efeito. De acordo com a descrição de uma analista contemporânea aos eventos: "De uma hora para outra, os especuladores viram-se em grandes dificuldades; a demanda por francos crescia aos saltos [...] O Banco da França pode comprar dólares e libras novamente [...] O movimento de alta foi tão intenso, porém, que nem mesmo essas grandes vendas de francos foram capazes de tolher a reação." ${ }^{" 77}$ No mesmo sentido, o próprio Raymond Phillipe, crítico severo de Poincaré, assim registrou em suas anotaçóes o resultado do uso dos empréstimos estrangeiros no mercado de divisas em março de 1924: "Foi possível ainda, ao embolsar um lucro importante para o Estado, reconstituir em poucos dias os quarenta e cinco milhões de dólares dos fundos Morgan que, por necessidade da luta, precisáramos mobilizar." ${ }^{" 78}$ Em suma, como uma sutil ironia da história, Poincaré, ainda que involuntariamente, naquele ponto em que contrariou o conselho dos experts terminou reforçando o objetivo maior por eles defendido, a desvalorização do franco.

\section{Considerações finais}

Sabe-se que, no mundo das coisas físicas, dois objetos não entram em atrito sem que ocorra alguma troca de matéria. No caso da estabilização do franco parece ter acontecido algo similar. Os embates entre o primeiro-ministro e o diretor geral do Banco da França, embora ríspidos, indicam haver resultado em certa assimilação dos pontos de vista contrários. No instante em que Moreau decide interferir no mercado cambial, as pré-condições para a estabilização que ele definira com o Conselho Geral, e até mesmo com Poincaré, certamente não haviam ainda se concretizado. A moeda se fortalecia a largas passadas, e a desvalorização preconizada pelo Comitê d'Experts se tornava cada vez mais débil a cada dia que o diretor geral relutava em agir. A sua hesitação, apesar dos renovados apelos de Quesnay e Rist, decorria, de uma parte, de um temor e, de outra, de uma dúvida. O temor residia na possibilidade de o legislativo vir a procrastinar a votação e a desfigurar a proposta orçamentária para o ano de 1927, como se tornara hábito na vida política do país. Os registros de Moreau do dia 15 de outubro deixam manifesta a sua preocupação a esse respeito: "As notícias que recebo são confluentes, ao descreverem o Governo como dividido e preocupado com a sua maioria parlamentar [...] Nessas condições, a prudência recomenda ao Banco da França não se envolver em especulaçōes no mercado de câmbio."79

Não foi, portanto, mero acaso a circunstância de o diretor geral haver se definido pela estabilização somente após a aprovação da peça orçamentária no dia 18 de dezembro, em sessão conjunta das duas casas legislativas. A primeira entrada dos registros do crucial 20 de dezembro enfatiza justamente esse acontecimento inédito: "Jamais, na memória humana, um orçamento foi votado de forma tão rápida, tão breve. Essa celeridade produziu profunda impressão na França e no estrangeiro." ${ }^{80}$ De outra parte, a dúvida de Moreau, particularmente sobre a conveniência de uma desvalorização acentuada da moeda, advinha do fato de que ele, assim como Poincaré, também se sensibilizar com a delicada condição dos pequenos credores do Estado. Ao final de novembro de 1926, quando recebe o representante da Inglaterra no Comitê Financeiro da Liga das Naçóes, Sir Arthur Salter, o visitante lhe indaga, com ar de incompreensão, o motivo da revalorização da moeda na França. Moreau estranha a pergunta, vinda de 
um defensor acirrado do retorno da libra à paridade-ouro do pré-guerra, mas responde de forma um tanto surpreendente: "No nosso país, não podemos sacrificar impunemente as classes médias por uma desvalorização muito forte de todos os capitais e rendimentos fixos."

Poincaré, de sua parte, não estava alheio à questão do nível de estabilização da moeda, como acreditava Moreau. ${ }^{82}$ Em seu admirável pronunciamento à Câmara dos Deputados, no início de fevereiro de 1928, embora circunspecto sobre o nível final da estabilização, ele indica, não obstante, as razões para a desvalorização adotada até ali pelo governo. Seu argumento revela grande apreensão com o estado da indústria nacional, acossada pelos avanços tecnológicos nos países vizinhos. Para Poincaré, no tocante à estabilização, deveriam prevalecer acima de tudo as consideraçôes técnicas do problema, reflexo presumível das preocupações de Moreau. Ou seja, a sustentação da conversibilidade ouro da moeda, segundo o primeiro-ministro, teria como pressuposto um balanço de pagamentos positivo, o que exigia um superávit na conta comercial e, por conseguinte, uma indústria doméstica competitiva. Em suas palavras: "Foi em função do seu interesse [do setor industrial] que nós, desde o início de 1927, suprimimos o imposto sobre a exportação. Foi em função do seu interesse que estabilizamos o franco num valor no qual ele não haveria espontaneamente se mantido." 83 Em junho do mesmo ano, no encaminhamento da lei oficializando o retorno ao padrão-ouro, o primeiro-ministro reforça o argumento, lamentando que a revalorização integral do franco, abrigada em seu coração, fosse como o jumento de Roland, detentor de todas as qualidades, mas com o único defeito de estar morto. "Nada", sentencia Poincaré, "sobreviveria a esse empreendimento temerário de saneamento, nem o orçamento, nem a indústria, nem a agricultura [...] toda a economia do país seria mortalmente ferida" ${ }^{84}$ Enfim, se as divergências entre os dois maiores protagonistas da estabilização da moeda francesa afiguravam-se irreconciliáveis em junho de 1926, a distância entre as suas concepções de política monetária parece ter se estreitado sensivelmente ao longo dos embates comuns, aplainando assim o pedregoso terreno no curso da recuperação financeira da nação.

\section{Notas}

${ }^{1}$ Aliança entre os partidos Esquerda Radical, Radical, Socialista SFIO e independentes para as eleiçôes de 11 de maio de 1924. O Cartel, apesar de seus 266 deputados e de contar com o apoio eventual de 26 comunistas, perante 276 deputados do grupo conservador, apresentava-se frágil por ter obtido apenas $48 \%$ dos votos, contra $51 \%$ do antigo Bloc National. Além disso, quase dois terços dos votos do Cartel haviam sido direcionados ao Partido Radical, organização política de centro com grande diversidade doutrinária, alinhado politicamente com a esquerda e financeiramente com os conservadores. Cf. BONNEFOUS, Édouard. Histoire politique de la Troisième République. L'après-Guerre (1919-1924). Tome Troisième. Deuxiéme edition. Paris: Presses Universitaires de France, [1959] 1968. p. 59-73, 431-437; CHASTENET, Jacques. Cent ans de République. Les années d'illusions, 1918-1931. Tome Cinquième. Paris: Jules Tallandier, 1970. p. 143-183; MAIER, Charles S. Recasting burgeois Europe. Stabilization in France, Germany and Italy after World War I. Princeton: PUP, 1988. p. $494-507$.

${ }^{2}$ Cf. SUAREZ, Georges. De Poincaré a Poincaré. Paris: Les Éditions de France, 1928. p. 137-242; BONNEFOUS, Édouard. Histoire politique de la Troisième République. Cartel des Gauches et Union Nationale (1924-1929). Tome Quatrième. Paris: Presses Universitaires de France, 1960. p. 144-164; Chastenet, op. cit., p. 173-183.

${ }^{3}$ Cf. BERSTEIN, Gisèle e BERSTEIN, Serge. Dictionnaire historique de la France contemporaine (DHFC). Tome 1, 18701945. Sabam: Editions Complexes, 1995. p. 10-12; YVERT, Benoît. Premiers ministres et présidents du Conseil depuis 1815. Paris: Perrin, 2002. p. 426-429.

${ }^{4}$ Cf. MARTIN, Benjamin F. The hypocrisy of justice in the Belle Epoque. Baton Rouge: Louisianna State University Press, 1984. p. 206-220.

${ }^{5}$ Caillaux tinha consciência das limitações políticas duradouras decorrentes de seu julgamento. Como expressou em suas Mémoires, ao comentar as propostas de tributação do capital durante o Cartel: "Tomando posição contra essas perigosas quimeras desde que retornei ao Louvre, que implicavam de 3 a 4 bilhões de aumento nos impostos, perdi quase imediatamente o apoio da esquerda avançada, enquanto a condenação pela Alta Corte que, apesar da anistia, pesava sobre a opinião parlamentar, me defrontou com a impossibilidade de unir em torno de mim uma maioria nacional. Quando [...] regressei ao governo que haveria de deixar em outubro de 1925 [na verdade, em julho de 1926] e solicitei ao Parlamento os plenos poderes julgados por mim e Briand como indispensáveis à rápida conclusão da complexa obra de saneamento financeiro, enfrentei o mesmo obstáculo". Cf. CAILLAUX, Joseph. Mes mémoires. Tome III. Clairvoyance et force d'âme dans les épreuves 1912-1930. Paris: Plon, 1947. p. 214-215; itálicos no original. 
${ }^{6}$ Cf. SUAREZ, op. cit., p. 1-14, 99-134; Bonnefous, 1960, op. cit. T. 4, p. 79-99, 144-159.

${ }^{7}$ Os termos "governador" e "subgovernador", empregados pelo autor, foram substituídos, respectivamente, por "diretor geral" e "subdiretor"; os termos "regente" e "Conselho de Regentes" (também usados pelo autor) foram eliminados, na medida em que entende-se que referem-se aos membros do Conselho Administrativo, ou Conselho Geral do Banco de França. As intervençōes no original objetivaram adequar à Língua Portuguesa, no campo semântico em questão, palavras e expressões empregadas nas línguas inglesa e francesa. Nota do Editor.

${ }^{8}$ Charles Georges Robineau (1860-1927) cresceu em Bar-le-Duc, juntamente com Poincaré, de quem foi amigo durante toda a vida. Ingressa em 1887 no Banco da França, onde realiza brilhante carreira. Torna-se Inspetor em 1897 e, no ano de 1892 é remanejado para o serviço de desconto, onde se converte em Diretor-Geral em 1912. No dia 25 de agosto de 1920 , assume o posto de Diretor Geral do Banco da França por designação do Presidente Alexandre Millerand, cargo no qual permanece até 1926, vindo a falecer no ano seguinte (Notas biográficas fornecidas pelo Banco da França).

${ }^{9}$ Ver SCHMID, Gregory C. The politics of currency stabilization: the French franc, 1926. In: Journal of European Economic History, v. 3, n. 2, p. 359-77, 1974; SCHUKER, Stephen. The end of French predominance in Europe. The financial crisis of 1924 and the adoption of the Dawes Plan. Chapel-Hill: The University of North Carolina Press, 1976; SARGENT, Thomas. Stopping moderate inflations: the methods of Poincaré and Tatcher. In: SARGENT, T. (Org.). Rational expectations and inflation. New York: Harper and Row, p. 110-157, 1986 ; SICSIC, Pierre. Was the Franc Poincaré deliberately undervalued? In: Explorations in Economic History, v. 29, n.1, p. 69-92, 1992; GIAMBIAGI, Fábio. O programa de estabilização de Raymond Poincaré. In: Pesquisa e Planejamento Econômico, v. 24, n. 3, p. 391-410, 1994; e BLANCHETON, Bertrand. Le Pape et l"Empereur. La Banque de France, la direction du Trésor et la polique monétaire de la France (19141928). Paris: Albin Michel, 2001.

${ }^{10}$ Ver MARKS, Sally. The illusion of peace. International relations in Europe, 1918-1933. London: Macmillan, 1982. Caps. 2-4; COSTIGLIOLA, Frank. Awkward dominion: American political, economic, and cultural relations with Europe, 19191933. Ithaca: Cornell University Press, 1984. Caps. 3-4; ORDE, Anne. British policy and European reconstruction after First World War. Cambridge: CUP, 1990. Caps. 5-8: EICHENGREEN, B. Golden fetters. The gold standard and the Great Depression 1919-1939. New York: Oxford University Press, 1992. Caps. 6-8.

${ }^{11}$ Cf. MOREAU, Emile. Souvenirs d'un gouverneur de la Banque de France. Histoire de la stabilization du franc (1926-1928). Paris: Librairie de Médicis, 1954.

${ }^{12}$ Cf. SUAREZ, op. cit., p. 59-89; BONNEFOUS, 1960, op. cit., T. 4, p. 144-145.

${ }^{13}$ Ver HAIG, Robert M. The public finances of post-War France. New York: Columbia University Press, 1929. Caps. X-VIII.

${ }^{14}$ Cf. MOULTON, Harold e LEWIS, Cleona. The French debt problem. New York: Macmillan, 1926. p. 57-68; BLANCHETON, Bertrand. Le Pape et l"Empereur. La Banque de France, la direction du Trésor et la polique monétaire de la France (1914-1928). Paris: Albin Michel, 2001. p. 93-103.

${ }^{15}$ Cf. SAUVY, A. e HIRSCH, A. Histoire économique de la France entre les deux guerres. Paris: Economica, 1984. v. II, p. 235-261.

${ }^{16}$ Chegou-se a criar, em 1920, um orçamento separado, composto por despesas denominadas recuperáveis (avances remboursables), as quais representariam antecipações do governo francês aos valores devidos pela Alemanha. O ministro das finanças do segundo gabinete Poincaré (1922-24), Charles de Lasteyrie, o conde deficitário, assim resumiu a questão em sua proposta de orçamento de 1923: "Antes de demandarmos novos sacrifícios do povo francês, é dever do governo lançar mão de todos os meios ao seu alcance para forçar a Alemanha a compensar toda ruína e destruição por ela causada” (apud HAIG, op. cit., p. 79). Logo adiante, porém, premido pela insuficiência de recursos, o conde viria a propor às pressas a reforma tributária de 1924 .

${ }^{17}$ Cf. POINCARÉ, Raymond. La restauration financière de la France. Discours prononcé à la Chambre des Députés les 3 et 4 février 1928. Paris: Payot, 1928. Annexe IA, Dette Publique 1926-1927; SAUVY e HIRSCH, op. cit., v. II, p. 297.

${ }^{18}$ A intransigência francesa no tocante às reparações alemãs tinha raízes históricas. Ao final da Guerra Franco-Prussiana de 1870 foi assinado o Tratado de Frankfurt (1871), estipulando o pagamento de pesadas reparaçôes pela França à Prússia, da ordem de cinco bilhões de francos ou aproximadamente uma quarta parte da renda nacional francesa de 1869 . O resgate desse débito, requisito para a retirada das forças de ocupação, viria a ser efetuado integralmente em quatro prestaçóes, na forma de ouro, divisas e letras comerciais. Cf. MOULTON e LEWIS, op. cit., p. 439-448; BLANCHETON, op. cit., p. 66-72.

${ }^{19}$ Em 9 de janeiro de 1923, a Comissão de Reparações declara a Alemanha em default nas entregas de carvão. Dois dias depois, Poincaré determina que forças francesas e belgas ocupem o distrito do Ruhr a fim de garantir a retomada dos carregamentos. Diante da resistência passiva da população local, apoiada financeiramente pelo governo alemão, o Reischmark entra em colapso, sendo arrastado em pouco tempo para a hiperinflação. A situação somente vem a se estabilizar com o fim da resistência passiva, a adoção do Rentenmark, em outubro de 1923, e o acordo dos industriais alemães com a MICUM (Mission Interalliée de Controle des Usines e des Mines), assinado em novembro. Em abril de 1924, o relatório da Comissão Dawes estabelece as bases para os pagamentos futuros de reparações. Na conferência de Londres, o novo primeiro-ministro Herriot assina um protocolo, em 17 de agosto, comprometendo-se a retirar as forças de ocupação num período de doze meses. Cf. 
BERGMANN, Carl. The history of reparations. Boston: Houghton Mifflin, 1927. p. 173-270; MOWAT, R. B. A history of European diplomacy 1914-1925. London: Edward Arnold, 1931. p. 243-278; CHASTENET, op. cit., T. 5, p. $115-155$. 20 Ver HERRIOT, Edouard. Jadis, d'une guerre a l'autre 1914-1936. Paris: Flamarion, 1952. p. 201; SAUVY e HIRSCH, op. cit. v. I, p. 40-42.

${ }^{21}$ Cf. CHASTENET, op. cit., T. 5, p. 158-160.

${ }^{22}$ MIQUEL, Pierre. Poincaré. Paris: Fayard, 1961. p. 525.

${ }^{23}$ Apud LACHAPELLE, Georges. Le credit public. Paris: Berger-Levrault, 1932. p. 111.

${ }^{24}$ Idem, ibidem, p. 143.

${ }^{25}$ Cf. SCHUKER, Stephen. The end of French predominance in Europe. The financial crisis of 1924 and the adoption of the Dawes Plan. Chapel-Hill: The University of North Carolina Press, 1976. p. 43.

${ }^{26}$ Apud BLANCHETON, op. cit., p. 227.

${ }^{27}$ Cf. SCHUCKER, 1976, op. cit., p. 45.

${ }^{28}$ A ação do presidente Norman tinha por ideal reerguer o sistema internacional de padrão-ouro por meio de uma rede de bancos centrais independentes das ingerências políticas e em contínuo contato entre si, com suas moedas lastreadas em divisas (gold-exchange standard), tendo Londres e Nova Iorque como núcleos depositários do estoque de ouro mundial. Num plano mais realista, ele buscava neutralizar o avanço financeiro norte-americano no continente europeu por meio da supervisão britânica dos processos nacionais de estabilização monetária. Norman, em verdade, tentava criar uma ampla área de influência da esterlina que servisse de anteparo ao surgimento de um novo centro de referência para o mundo anglo-saxão. Ver BOYLE, Andrew. Montagu Norman. London: Cassel, 1967. Caps. 7 e 8; COSTIGLIOLA, Frank. "Anglo-American financial rivalry in the 1920s". In: The Journal of Economic History, v. 37, n. 4, p. 911-934, Dec 1977; FERRIS, John R. Men, money and diplomacy. The evolution of British strategic foreign policy, 1919-1926. Ithaca: Cornell University Press, 1989. Caps. 3 e 6; PÉTERI, Györy. "Central bank diplomacy: Montagu Norman and Central Europe’s monetary reconstruction after World War I”. In: Contemporary European History, v. 1, n. 3, p. 233-258, Nov 1992.

${ }^{29}$ Cf. PHILLIPE, PHILLIPE, Raymond. Le drame financier de 1924-1928. Paris: Galimard, 1931. p. 104-106.

${ }^{30} \mathrm{O}$ Comité d'Experts era constituído pelos seguintes membros: Charles Sargent, presidente da Comissão e do Banque de l'Union Parisienne, Lewandowsky, administrador do Comptoir National d'Escompte, Robert Masson, diretor do Crédit Lyonnais, Henri de Peyerimhoff, presidente do Comité des Houllières, Raymond Phillipe, associado à casa Lazard Frères, Joseph Simon, vice-presidente da Societé Générale, René Duchemin, presidente da Confédération Générale de la Production Française, Ernest-Picard, subdiretor do Banco da França, Emile Moreau, diretor geral do Banque d'Algerie, Etienne Fougère, Presidente da Associacion Nacionale d'Expansion Économique, Emile Oudot, diretor geral do Banque de Paris et des Pays-Bas, Gaston Jéze e Charles Rist, professores da Faculdade de Direito de Paris. Cf. BLANCHETON, op. cit., p. 361.

${ }^{31}$ Cf. COMITÉ D’EXPERTS. Le rapport du Comité d'Experts. Résumé officiel. In: Journal des Economistes, p. 63-72, Juil. 1926; LACHAPELLE, op. cit., p. 275.

32 Jacques Rueff, inspetor das finanças à época do gabinete de Union Nationale de Poincaré, escreveria anos depois a respeito das raras manifestações contrárias à revalorização: "Aqueles que não vivenciaram o problema da estabilização não podem mensurar a coragem intelectual e moral, nem mesmo o risco pessoal que tal decisão implicava. Todos os cegos, os fracos, os pusilânimes ou mesmo os simples complacentes, a quase totalidade dos economistas ortodoxos, eram favoráveis ao retorno da paridade do pré-guerra”. Cf. RUEFF, Jacques. "La stabilisation du franc”. In: Revue d’Économie Politique, v. 65, p. 923-926, 1955.

${ }^{33}$ Cf. Relatório dos Especialistas apud SAUVAIRE-JOURDAN, F. "Le Rapport du Comité d'Experts et la revalorisation du franc”. In: Révue d'Economie Politique, v. 6, Nov-Dec 1926. p. 1287-1288.

Como explicaria Rist mais tarde: "[O] texto do relatório consistia, sobretudo, numa condenação da política de imobilismo do Banco da França que pretendia nada mudar no preço legal do ouro e acreditava que o Governo sozinho, ao equilibrar o orçamento, viria a fazer o franco remontar à sua paridade anterior. Era M. Édouard de Rotschild, particularmente, considerado pelos membros do Conselho do Banco e pelo Governo como uma grande autoridade, que defendia essa tese absurda". Cf. RIST, Charles. "Noticie biographique”. In: Revue d'Économie Politique, v. 65, 1955. p. 998.

${ }^{34}$ Apud JEANNENEY, Jean-Noël. François de Wendel en République. L'argent et le pouvoir 1914-1940. Paris: SEUIL, 1976. p. 285.

${ }^{35}$ Cf. PHILLIPE, op. cit., p. 96-97.

${ }^{36}$ Cf. PHILLIPE, op. cit., p. 39-56; LACHAPELLE, op. cit., p. 164-175.

${ }^{37}$ Cf. JEANNENEY, op. cit., p. 194-214; BLANCHETON, op. cit., p. 233-250. Jeanneney (p. 207-211) mostra que as falsificações remontavam, com efeito, aos tempos do Bloc National, iniciadas em março de 1924 sob os auspícios do secretário geral do Banco da França, Albert Aupetit, como forma de minorar o valor da circulação fiduciária e facilitar, desse modo, a defesa do franco conduzida por Poincaré na ocasião. O diretor geral Robineau saberia igualmente do procedimento, tendo julgado-o vantajoso por seus resultados imediatos. 
${ }^{38}$ Cf. HERRIOT, op. cit., p. 199-226.

${ }^{39}$ Idem, ibidem, p. 226.

${ }^{40}$ Cf. CAILLAUX, op. cit., p. 216.

${ }^{41}$ Cf. SUAREZ, op. cit., p. 161.

${ }^{42}$ Emile Hilaire Aimé Moreau (1868-1950) nasce em Poitiers, obtém Licença em Direito na Escola Livre de Ciências Políticas em Paris e ingressa na Administração das Finanças em 1893 e se torna Inspetor em 1898. De 1902 a 1906, é chefe de gabinete de Maurice Rouvier, primeiro no Ministério das Finanças e, após, no de Assuntos Estrangeiros. Nesse último ano, assume a função de Diretor Geral do Banco da Argélia, cargo que deixará apenas em 1926, quando é nomeado Diretor Geral do Banco da França, onde permanece até 1930. A seguir, preside o conselho de administração do banco de Paris et de PaysBas, do qual se retira em 1941 (Notas biográficas fornecidas pelo Banco da França).

${ }^{43}$ Nos seus primeiros dias à testa do Banco da França, Moreau encaminha a concessão de pensões a Robineau, Picard e Aupetit, demite o diretor da carteira de descontos da instituição, M. Kempf, por considerá-lo responsável pela aceitação de papéis comanditários de qualidade duvidosa, além de combinar com Leclerc e Rist os primeiros passos para criar na instituição um serviço permanente de atuação no mercado de câmbio.

${ }^{44}$ Cf. MOREAU, op. cit., p. 14-15.

${ }^{45}$ Empréstimo negociado por Clémentel junto à casa dos Morgan, nos Estados Unidos, em novembro de 1924 (na verdade, renovação daquele concedido em maio do mesmo ano), tendo como garantia obrigações do Tesouro a 7\%, cujo produto seria depositado no Banco da França. O empréstimo Morgan deveria servir como promoção do bom crédito externo do ministério das finanças, estimulando o público a adquirir os títulos decenais do Tesouro com taxa de 5\%, negociados entre novembro e dezembro daquele ano. O sucesso da emissão doméstica, contudo, ficou aquém do esperado e distante, portanto, de resolver o problema de caixa do governo. Cf. LACHAPELLE, op. cit., p. 197-203.

${ }^{46}$ Cf. MOREAU, op. cit., p. 37.

${ }^{47}$ Idem, ibidem, p. 38.

${ }^{48}$ Cf. BONNEFOUS, 1960, op. cit., T. 4, p. 167.

${ }^{49}$ No inverno daquele ano, especuladores externos conduzem um ataque coordenado ao franco. Poincaré mobiliza o Tesouro para promover uma reforma tributária, bem como o Banco da França para negociar empréstimos externos de 100 milhōes de dólares junto à casa Morgan e de 4 milhões de libras esterlinas com a filial londrina do banco Lazard Frères. As divisas obtidas são lançadas no mercado e revertem em pouco tempo o movimento de baixa da moeda. Cf. DULLES, Eleanor L. The French franc 1914-1928. The facts and their interpretation. New York: Macmillan, 1929. p. 170-178; WOLFE, Martin. The French franc between the wars 1919-1939. New York: AMS, 1950. p. 33-35; KINDLEBERGER, Charles P. A financial history of Western Europe. London: Allen \& Unwin, 1984. p. 350-355.

${ }^{50}$ A dívida de guerra da França com os Estados Unidos, no ano de 1924, somava 3,7 bilhões de dólares e, com a Inglaterra, 627 milhões de libras. A França entendia que tais valores sequer deveriam ser cobrados por se tratarem de parte do esforço de guerra aliado. Eventual reconhecimento do débito, porém, deveria conter uma cláusula condicionando os pagamentos ao ingresso dos recursos de reparação. Essas posições não eram compartilhadas pelos Estados Unidos, que impuseram um embargo financeiro ao país até a resolução definitiva da questão. Em abril de 1926, o embaixador francês Henry Bérenger e o secretário do Tesouro norte-americano Andrew Mellon estabelecem um acordo para liquidação do débito em 62 parcelas anuais. Caillaux, antecipando a recomendação dos experts, assina um acordo com Churchill, em julho de 1926, para o pagamento da dívida com a Inglaterra, também em 62 anuidades, mas com reservas em caso de lapso nas reparaçôes. A ratificação final desses entendimentos teria lugar apenas em 26 de julho de 1929. Cf. BONNEFOUS, 1960, op. cit., T. 4, p. 134-135, 154-155, 352-359; RHODES, Benjamin D. "Uncle Shylock": The United States and the French war debt, $1917-$ 1929. In: The Journal of American History, v. 55, n. 4, p. 787-803, Mar 1969.

${ }^{51}$ Cf. MOREAU, op. cit., p. 45.

52 Apud BLANCHETON, op. cit., p. 389.

${ }^{53}$ Entende-se, portanto, a preocupação constante de Poincaré com o destino de Aupetit após a demissão do mesmo (Cf. MOREAU, op. cit., p. 84, 99, 149, 236). Assim, por exemplo, escreve Moreau em suas anotaçóes do dia 8 de setembro de 1926, refletindo as dificuldades enfrentadas pelo ex-secretário nos círculos bancários após a descoberta dos relatórios falsificados: "No final do dia, M. Laroze, diretor geral do Crédit Foncier, me informa que M. Poincaré lhe sugeriu aceitar M. Aupetit como seu subdiretor, mas que ele [Laroze] havia recusado" (Idem, ibidem, p. 99).

${ }^{54}$ Cf. MOREAU, op. cit., p. 55.

${ }^{55}$ Moureau narra nos seguintes termos sua conversa com o barão em 10 de agosto de 1926: "Sobre esse assunto [a compra de divisas], visito o barão de Rotschild cuja oposição é de se respeitar [...] No curso da conversação, o barão Édouard me parece fundamentalmente hostil à estabilização e partidário de uma larga revalorização do franco (Cf. MOREAU, op. cit., p. 70. Ver também a entrada do dia 4 de setembro, p. 95, na qual o barão ameaça se demitir do Conselho, caso o Banco viesse a comprar ouro ou divisas fora das antigas cotaçōes). 
${ }^{56}$ Cf. MOREAU, op. cit., p. 60.

${ }^{57}$ Cf. CHASTENET, op. cit., T. 5, p. 188-189.

${ }^{58}$ Cf. MOREAU, op. cit., p. 66.

${ }^{59}$ Nesse ínterim, Moureau investiga a suspeita de Leclerc relativa ao funcionamento de um posto de escuta capaz de acompanhar as conversas de toda a esfera administrativa do Banco e, por isso, recomenda prudência a Rist e Quesnay em suas manifestações. O secretário Strohl confirma a existência das instalações. Moreau determina a destruição imediata de todo o aparato. Cf. MOREAU, op. cit., p. 75.

${ }^{60}$ Em conformidade com a lei de 7 de agosto, o Banco inicia, em 27 de setembro de 1926, a aquisição de lingotes de ouro e de moedas cunhadas em ouro, a preço variável, iniciativa que se revela um grande sucesso e resulta num total acumulado de 250 mil quilos do metal, vendido nos guichês da instituição até o dia 11 de outubro do mesmo ano Cf. MOREAU, op. cit., p. 129.

${ }^{61}$ Cf. MOREAU, op. cit., p. 101.

${ }^{62}$ Idem, ibidem, p. 166.

${ }^{63}$ Idem, ibidem.

${ }^{64}$ Idem, ibidem, p. 122.

${ }^{65}$ Idem, ibidem, p. 139.

${ }^{66}$ Idem, ibidem, p. 152.

${ }^{67}$ Idem, ibidem, p. 163.

${ }^{68}$ Idem, ibidem, p. 165.

${ }^{69}$ Cf. LACHAPELLE, op. cit., p. 328.

${ }^{70}$ Cf. MOREAU, op. cit., p. 182-183.

${ }^{71}$ A cotação do franco germinal em dólares era de 19,3 cents ou 322 miligramas de ouro. Quando é legalizada a razão de troca de 65,5 miligramas de ouro por unidade monetária, pela lei de 25 de junho de 1928, resulta uma paridade de quatro cents (four-sou) por franco. A liquidação integral dos débitos do Tesouro junto ao Banco da França sucederia quando da passagem dessa lei, que permitiu a reavaliação do estoque total de ouro da instituição à nova paridade legal da moeda $(1914=25,2$ francos por libra, 1928=124,2 francos por libra), fornecendo um saldo positivo lançado na rubrica de amortização das dívidas do governo e do qual restaram ainda 2 bilhões de francos creditados na conta corrente do Tesouro. Cf. LACHAPELLE, op. cit., p. 377-388; WOLFE, op. cit., p. 50-53.

72 Para a emoção do diretor geral com a homenagem, ver MOREAU, op. cit., p. 235-236.

${ }^{73}$ Ver a crítica de PHILLIPE, op. cit., p. 117-123.

${ }^{74}$ Benjamin Strong, presidente do Federal Reserve Bank of New York, manteve vários entendimentos com Moreau e Rist entre julho e setembro de 1926 a respeito dos elementos essenciais à estabilização do franco, não deixando de reiterar a seus colegas o imperativo de independência do banco central e de solucionar-se de vez o problema da dívida francesa com os Estados Unidos. Cf. MOREAU, op. cit., p. 56-57, 91-92, 100-103. Sobre as relaçōes entre os dois dirigentes e os problemas envolvendo a cooperação entre os bancos centrais europeus à época, ver, por exemplo, CLARKE, Stephen O. Central bank cooperation 1924-31. New York: Federal Reserve Bank of New York, 1967, caps. 4-7 e MOURÉ, Kenneth. "The limits to central bank co-operation, 1916-36". In: Contemporary European History, v. 2, n. 3, p. 259-279, 1992.

${ }^{75}$ Cf. MOREAU, op. cit., p. 125. Para iniciativas similares do Bankers Trust, do Irving Bank e do banco Morgan, consulte-se as páginas $22,112,158$.

${ }^{76} \mathrm{O}$ presidente do Reischbank, Hjalmar Schacht, em suas memórias, condenou repetidamente o endividamento irresponsável do país após o plano Dawes promovido pela facilidade de obtenção do dinheiro norte-americano: "Os agentes estrangeiros praticamente sitiavam os grandes industriais e as autoridades municipais com ofertas de empréstimos. Era quase impossível passar pelo Hotel Adlon, Unter der Linden, sem ser interpelado por algum corretor financeiro a perguntar sobre a existência de negócios ou de entidades municipais para as quais ele pudesse oferecer um empréstimo". Cf. SCHACHT, Hjalmar. My first seventy-six years. London: Allan Wingate, 1955. p. 219.

${ }^{77}$ Cf. DULLES, op. cit., p. 175.

${ }^{78}$ Cf. PHILLIPE, op. cit., p. 46.

${ }^{79}$ Cf. MOREAU, op. cit., p. 131. A preocupação de Moreau refletia o congresso do Partido Radical, transcorrido em Bordeaux entre os dias 14 e 16 de outubro de 1926, mais uma vez dividido entre o apoio ao governo Poincaré e a união eleitoral com a esquerda. Herriot reafirma sua adesão ao governo como um imperativo moral por atender ao apelo da pátria, sendo sucedido na presidência do Partido pelo moderado Maurice Sarraut. Em seu documento final, o congresso declara fidelidade à união das esquerdas para as eleições senatoriais e a continuidade da sustentação ao governo de Union Nationale de Poincaré. Cf. SOULIÉ, Michel. La vie politique d'Édouard Herriot. Rennes: Armand Colin, 1962. p. 280-282; SCHLE- 
SINGER, Mildred. "The development of the radical party in the Third Republique: the new radical movement, 1926-32". In: The Journal of Modern History, v. 46, n. 3, p. 476-51, Sep 1974.

${ }^{80}$ Cf. MOREAU, op. cit., p. 181.

${ }^{81}$ Idem, ibidem, p. 170.

${ }^{82}$ No seu prefácio aos Souvenirs, Rueff mostra como o secretário geral da C.G.T., Leon Jouhaux, visitou diversas vezes o presidente do conselho para lhe esclarecer a respeito dos riscos de uma alta desmesurada do franco sobre o volume de emprego do país. Rueff lembra igualmente como, ainda jovem inspetor das finanças, foi requisitado por Poincaré a preparar um estudo sobre o patamar mais recomendável para a fixação do valor do franco. O relatório, concluído em novembro de 1926, prescrevia uma taxa entre 120 e 145 francos pela libra esterlina, na vizinhança daquela que viria a ser efetivamente praticada a seguir. Cf. Cf. MOREAU, op. cit., p. viii-ix.

${ }^{83}$ Cf. POINCARÉ, op. cit., p. 132.

${ }^{84}$ Apud LACHAPELLE, op. cit., p. 368.

\section{Referências bibliográficas}

BERGMANN, Carl. The history of reparations. Boston: Houghton Mifflin, 1927.

BERSTEIN, Gisèle e BERSTEIN, Serge. Dictionnaire historique de la France contemporaine (DHFC). Tome 1, 1870-1945. Sabam: Editions Complexes, 1995.

BLANCHETON, Bertrand. Le Pape et l'Empereur. La Banque de France, la direction du Trésor et la polique monétaire de la France (1914-1928). Paris: Albin Michel, 2001.

BONNEFOUS, Édouard. Histoire politique de la Troisième République. Laprès-Guerre (1919-1924). Tome Troisième. Deuxiéme edition. Paris: Presses Universitaires de France, [1959] 1968.

BONNEFOUS, Édouard. Histoire politique de la Troisième République. Cartel des Gauches et Union Nationale (1924-1929). Tome Quatrième. Paris: Presses Universitaires de France, 1960.

BOYLE, Andrew. Montagu Norman. London: Cassel, 1967.

CAILLAUX, Joseph. Mes mémoires. Tome III. Clairvoyance et force d'âme dans les épreuves 1912-1930. Paris: Plon, 1947.

CHASTENET, Jacques. Cent ans de République. Les années d'illusions, 1918-1931. Tome Cinquième. Paris: Jules Tallandier, 1970.

CLARKE, Stephen O. Central bank cooperation 1924-31. New York: Federal Reserve Bank of New York, 1967. COMITÉ D’EXPERTS. “Le rapport du Comité d'Experts. Résumé officiel”. In: Journal des Economistes, p. 63-72, Juil. 1926.

COSTIGLIOLA, Frank. "Anglo-American financial rivalry in the 1920s". In: The Journal of Economic History, v. 37, n. 4, p. 911-934, Dec 1977.

COSTIGLIOLA, Frank. Awkward dominion: American political, economic, and cultural relations with Europe, 1919-1933. Ithaca: Cornell University Press, 1984.

DULLES, Eleanor L. The French franc 1914-1928. The facts and their interpretation. New York: Macmillan, 1929.

EICHENGREEN, B. Golden fetters. The gold standard and the Great Depression 1919-1939. New York: Oxford University Press, 1992.

FERRIS, John R. Men, money and diplomacy. The evolution of British strategic foreign policy, 1919-1926. Ithaca: Cornell University Press, 1989.

GIAMBIAGI, Fábio. "O programa de estabilização de Raymond Poincaré". In: Pesquisa e Planejamento Econômico, v. 24, n. 3, p. 391-410, 1994.

HAIG, Robert M. The public finances of post-War France. New York: Columbia University Press, 1929.

HERRIOT, Edouard. Jadis, d'une guerre a l'autre 1914-1936. Paris: Flamarion, 1952.

JEANNENEY, Jean-Noël. François de Wendel en République. L'argent et le pouvoir 1914-1940. Paris: SEUIL, 1976.

KINDLEBERGER, Charles P. A financial history of Western Europe. London: Allen \& Unwin, 1984.

LACHAPELLE, Georges. Le credit public. Paris: Berger-Levrault, 1932. 
MAIER, Charles S. Recasting burgeois Europe. Stabilization in France, Germany and Italy after World War I. Princeton: PUP, 1988.

MAKINEN, Gail E., WOODWARD, Thomas G. "A monetary interpretation of the Poincaré stabilization of 1926”. In: Southern Economic Journal, v. 14, n. 1, p. 191-211, 1988.

MARKS, Sally. The illusion of peace. International relations in Europe, 1918-1933. London: Macmillan, 1982.

MARTIN, Benjamin F. The hypocrisy of justice in the Belle Epoque. Baton Rouge: Louisianna State University Press, 1984.

MIQUEL, Pierre. Poincaré. Paris: Fayard, 1961.

MOULTON, Harold e LEWIS, Cleona. The French debt problem. New York: Macmillan, 1926.

MOREAU, Emile. Souvenirs d'un gouverneur de la Banque de France. Histoire de la stabilization du franc (19261928). Paris: Librairie de Médicis, 1954.

MOURÉ, Kenneth. "The limits to central bank co-operation, 1916-1936". In: Contemporary European History, v. 2, n. 3, p. 259-279, 1992.

MOWAT, R. B. A history of European diplomacy 1914-1925. London: Edward Arnold, 1931.

ORDE, Anne. British policy and European reconstruction after First World War. Cambridge: CUP, 1990.

PÉTERI, Györy. "Central bank diplomacy: Montagu Norman and Central Europe's monetary reconstruction after World War I”. In: Contemporary European History, v. 1, n. 3, p. 233-258, Nov 1992.

PHILLIPE, Raymond. Le drame financier de 1924-1928. Paris: Galimard, 1931.

POINCARÉ, Raymond. La restauration financière de la France. Discours prononcé à la Chambre des Députés les 3 et 4 février 1928. Paris: Payot, 1928.

RHODES, Benjamin D. “Uncle Shylock': The United States and the French war debt, 1917-1929”. In: The Journal of American History, v. 55, n. 4, p. 787-803, Mar 1969.

RIST, Charles. "Noticie biographique". In: Revue d'Économie Politique, v. 65, p. 977-1045, 1955.

RUEFF, Jacques. "La stabilisation du franc”. In: Revue d'Économie Politique, v. 65, p. 923-926, 1955.

SARGENT, Thomas. "Stopping moderate inflations: the methods of Poincaré and Tatcher". In: SARGENT, T. (Org.). Rational expectations and inflation. New York: Harper and Row, p. 110-157, 1986.

SAUVAIRE-JOURDAN, F. "Le Rapport du Comité d'Experts et la revalorisation du franc". In: Révue d'Economie Politique, v. 6, p. 1281-1299, Nov-Dec 1926.

SAUVY, A. e HIRSCH, A. Histoire économique de la France entre les deux guerres. Vs. I, II. Paris: Economica, 1984. SCHACHT, Hjalmar. My first seventy-six years. London: Allan Wingate, 1955.

SCHLESINGER, Mildred. "The development of the radical party in the Third Republique: the new radical movement, 1926-32". In: The Journal of Modern History, v. 46, n. 3, p. 476-51, Sep 1974.

SCHUKER, Stephen. The end of French predominance in Europe. The financial crisis of 1924 and the adoption of the Dawes Plan. Chapel-Hill: The University of North Carolina Press, 1976.

SCHMID, Gregory C. "The politics of currency stabilization: the French franc, 1926". In: Journal of European Economic History, v. 3, n. 2, p. 359-77, 1974.

SICSIC, Pierre. "Was the Franc Poincaré deliberately undervalued?" In: Explorations in Economic History, v. 29, n.1, p. 69-92, 1992.

SOULIÉ, Michel. La vie politique d'Édouard Herriot. Rennes: Armand Colin, 1962.

SUAREZ, Georges. De Poincaré a Poincaré. Paris: Les Éditions de France, 1928.

WOLFE, Martin. The French franc between the wars 1919-1939. New York: AMS, 1950.

YVERT, Benoît. Premiers ministres et présidents du Conseil depuis 1815. Paris: Perrin, 2002. 


\title{
RESUMO
}

O artigo trata da estabilização do franco, ocorrida no segundo semestre de 1926, privilegiando a perspectiva fornecida pelos registros diários do novo diretor geral do Banco da França à época, Emile Moreau. Na primeira parte, procede-se a uma reconstrução do quadro politico francês na fase de dissolução do Cartel des Gauches. A seguir, examinam-se as novas bases de estabilização da moeda propostas pelo Comité d'Experts, juntamente com os determinantes da remoção da cúpula dirigente do Banco da França pelo ministro das finanças Joseph Caillaux. Após, são apresentadas as principais medidas de politica monetária adotadas por Moreau, bem como suas divergências com o primeiro-ministro, Raymond Poincaré, a respeito da estratégia de recuperação econômica do pais. Ao final, avalia-se até que ponto as visöes de Poincaré e Moreau realmente se distanciavam em relação à magnitude mais conveniente de estabilização do câmbio. Palavras-chave: padrão-ouro, franco francês, Banco da França, Emile Moreau, Raymond Poincaré.

\begin{abstract}
This paper discusses the French franc stabilization process, happened in the second half of 1926, focusing on the perspective offered by the recorded daily memories of the new governor of the Bank of France at the time, Emile Moreau. The first section covers the French political scene in the period of the Cartel des Gauches dissolution. After that, the new basis for the monetary stabilization provided by the Comite d'Experts are examined, as well as the main factors behind the dismissal of the Bank of France's top executive rank by the minister of finance Joseph Caillaux. Next, Moreau's main monetary policy actions are presented, along with his clashes with Prime Minister Raymond Poincaré over the best strategy toward the country's economic recovery. The concluding remarks assess how far apart indeed were Poincare and Moreau's conceptions about the most appropriate level for stabilizing the exchange rate.

Keywords: gold-standard, French franc, Bank of France, Emile Moreau, Raymond Poincaré.
\end{abstract}

